\title{
Article \\ The Role of Estriol and Estrone in Keratoconic Stromal Sex Hormone Receptors
}

\author{
Paulina Escandon ${ }^{1,2}$, Sarah E. Nicholas ${ }^{1,2}$, Rebecca L. Cunningham ${ }^{2}$, David A. Murphy ${ }^{3}$, Kamran M. Riaz ${ }^{3}$ \\ and Dimitrios Karamichos $1,2,4, * \mathbb{B}$
}

1 North Texas Eye Research Institute, University of North Texas Health Science Center, Fort Worth, TX 76107, USA; paulina.escandon@unthsc.edu (P.E.); sarah.nicholas@unthsc.edu (S.E.N.)

2 Department of Pharmaceutical Sciences, University of North Texas Health Science Center, Fort Worth, TX 76107, USA; rebecca.cunningham@unthsc.edu

3 Department of Ophthalmology, Dean McGee Eye Institute, University of Oklahoma Health Sciences Center, Oklahoma City, OK 73104, USA; david-murphy@dmei.org (D.A.M.); kamran-riaz@dmei.org (K.M.R.)

4 Department of Pharmacology and Neuroscience, University of North Texas Health Science Center, Fort Worth, TX 76107, USA

* Correspondence: Dimitrios.Karamichos@unthsc.edu; Tel.: +1-817-735-2101

\section{check for} updates

Citation: Escandon, P.; Nicholas, S.E.; Cunningham, R.L.; Murphy, D.A.; Riaz, K.M.; Karamichos, D. The Role of Estriol and Estrone in Keratoconic Stromal Sex Hormone Receptors. Int. J. Mol. Sci. 2022, 23, 916. https:// doi.org/10.3390/ijms23020916

Academic Editor: M. Elizabeth Fini

Received: 17 November 2021

Accepted: 8 January 2022

Published: 14 January 2022

Publisher's Note: MDPI stays neutral with regard to jurisdictional claims in published maps and institutional affiliations.

Copyright: (C) 2022 by the authors. Licensee MDPI, Basel, Switzerland. This article is an open access article distributed under the terms and conditions of the Creative Commons Attribution (CC BY) license (https:// creativecommons.org/licenses/by/ $4.0 /)$.

\begin{abstract}
Keratoconus $(\mathrm{KC})$ is a progressive corneal thinning disease that manifests in puberty and worsens during pregnancy. $\mathrm{KC}$ onset and progression are attributed to diverse factors that include: environmental, genetics, and hormonal imbalances; however, the pathobiology remains elusive. This study aims to determine the role of corneal stroma sex hormone receptors in $\mathrm{KC}$ and their interplay with estrone (E1) and estriol (E3) using our established 3D in vitro model. Healthy cornea stromal cells (HCFs) and KC cornea stromal cells (HKCs), both male and female, were stimulated with various concentrations of E1 and E3. Significant changes were observed between cell types, as well as between males and females in the sex hormone receptors tested; androgen receptor (AR), progesterone receptor $(\mathrm{PR})$, estrogen receptor alpha $(\mathrm{ER} \alpha)$, and estrogen receptor beta (ER $\beta)$ using Western blot analysis. E1 and E3 stimulations in HCF females showed AR, PR, and ER $\beta$ were significantly upregulated compared to HCF males. In contrast, ER $\alpha$ and ER $\beta$ had significantly higher expression in HKC's females than HKC's males. Our data suggest that the human cornea is a sex-dependent, hormone-responsive tissue that is significantly influenced by E1 and E3. Therefore, it is plausible that E1, E3, and sex hormone receptors are involved in the $\mathrm{KC}$ pathobiology, warranting further investigation.
\end{abstract}

Keywords: keratoconus; sex hormones; cornea

\section{Introduction}

Keratoconus $(\mathrm{KC})$ is a progressive disorder in which the normally "round" cornea thins and bulges out, resulting in significant vision impairment. The complexity of $\mathrm{KC}$ in the context of progression, onset, and pathology is still not well understood. KC affects both males and females [1] and contributing factors include: genetics [2-7], environment (external factors) [2,4], hormonal imbalances [8,9], and physical eye rubbing [10-14]. Sex and age have been associated with the onset of $\mathrm{KC}$, beginning in adolescence [15-17] and with significant exacerbation during pregnancy $[16,18-20]$, coinciding with major hormonal changes.

Sex hormone changes in KC have been recently implicated in its pathogenesis [9,18,21,22]. Sex hormones are accessible to all tissues through blood circulation; however, specific receptors are required for these hormones to function and have an impact. During pregnancy, the fluctuation of sex hormones has been correlated to causing corneal alterations in curvature, central corneal thickness, and corneal volume [23-25]. It is believed that these hormonal changes exacerbate the progression of $\mathrm{KC}$ during pregnancy and can extend up to six 
months postpartum [18]. In addition, one study has shown that changes in estrogen levels during menopause were associated with alterations in corneal curvature in females [26].

Expression of sex hormone receptors in the human cornea has been reported; however, their role and function pertaining to corneal processes are still unclear [27-31]. In addition, the presence of sex hormone receptors in other ocular tissues such as lens [30,32], retina [30,33], lacrimal gland [30,34], iris [30,32], and ciliary body [30] have been reported, as well as sex hormone influence in structure and function of lacrimal glands impacting ocular diseases such as dry eye [35]. It is, therefore, critical to delineate the interplay between $\mathrm{KC}$, sex hormones, and their receptors.

Levels of estrogen-derived hormones estrone (E1) and estriol (E3), are of particular interest as they fluctuate during puberty, menstruation, pregnancy, and menopause, suggesting a possible impact on the KC pathobiology. To date, there is no evidence on whether E1 and E3 fluctuations affect corneal homeostasis in KC. Interestingly, our group has previously reported that both, E1 and E3 are downregulated in KC blood (plasma) and saliva samples compared to their healthy counterparts, independent of age, sex, or KC severity [22]. The impact of E1/E3 in KC-stromal microenvironment (i.e., in vitro) has yet to be investigated.

In the current study, we investigated the effects of E1 and E3 on sex hormone receptors present in corneal stromal cells derived from healthy and keratoconus donors, utilizing our established 3D KC self-assembled ECM in vitro model. Overall, our data reveal for the first time, the impact of E1 and E3 on sex hormone receptors present in KC corneal stromal cells and highlights their sex-dependent modulation.

\section{Results}

Sex hormone receptors $\mathrm{AR}, \mathrm{PR}, \mathrm{ER} \alpha$, and $\mathrm{ER} \beta$ expression was examined using Western blot assays for both HCF and HKC constructs post-stimulation of E1 or E3 for 4 weeks. Fold change of sex hormone receptors expression to GAPDH (housekeeping) expression are demonstrated in the results. The overall sex hormone receptor expression was analyzed from two HCFs and two HKCs cornea donors, where each cornea donor was performed in triplicate, making an $n=6$ per cell type. Data were also stratified by sex in both HCFs (one female and one male) and HKCs (one female and one male) cornea donors, with each cornea donor constructs performed in triplicate making an $n=3$ per sex-cell type.

\subsection{Impact of E1 on Sex Hormone Receptors}

Protein expression was investigated for AR, PR, ER $\alpha$, and ER $\beta$ in $3 \mathrm{D}$ HCF and HKC constructs in response to 10,50 , and $150 \mathrm{ng} / \mathrm{mL}$ E1 stimulation at four weeks. Data were also stratified by sex in both HCFs and HKCs.

\subsubsection{Androgen Receptor}

The overall AR expression between HCFs and HKCs showed significant upregulation in HCF controls when compared to HKC controls (Figure 1A). However, E1 stimulation did not show substantial differences in AR expression between HCFs and HKCs (Figure 1A).

In terms of sex-specific AR expression in HCFs, females showed significantly higher expression than males in all E1 concentrations tested (Figure 1B). In addition, expression of AR in HCF females was upregulated significantly when stimulated with $150 \mathrm{pg} / \mathrm{mL}$ of E1 compared to HCF male controls (Figure 1B). Interestingly, sex-specific AR expression in HKCs showed no significant changes (Figure 1C).

No statistically significant differences were observed when comparing the malespecific AR expression in HCFs or HKCs (Figure 1D). On the other hand, the female-specific AR expression was significantly downregulated in HKC females compared to HCF females under all E1 concentrations (Figure 1E). 


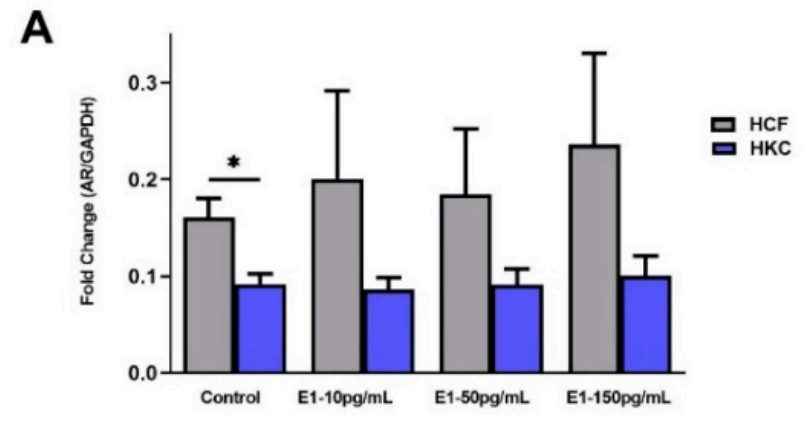

B

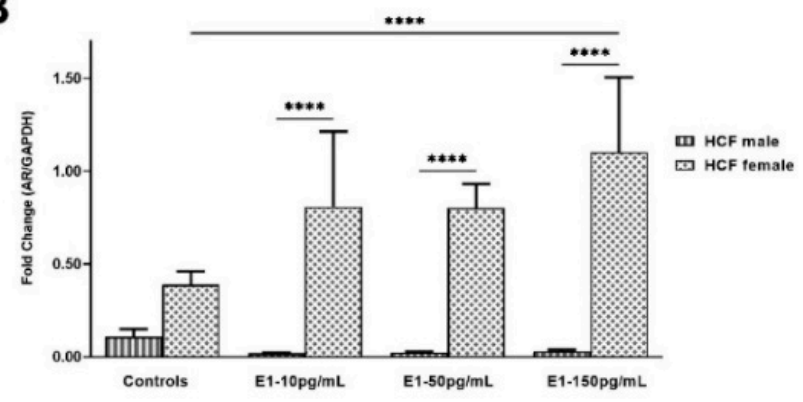

D

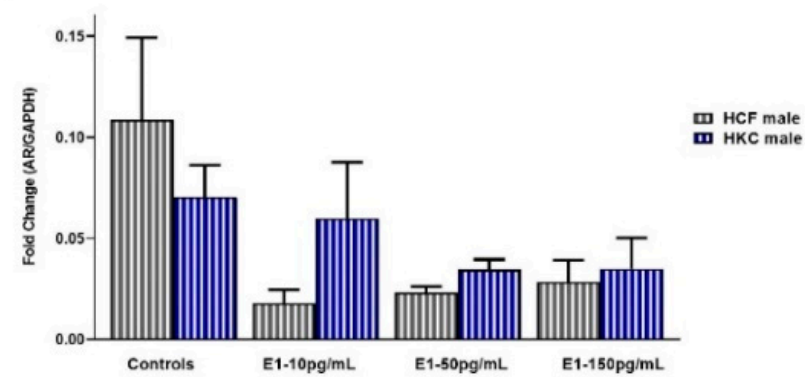

C

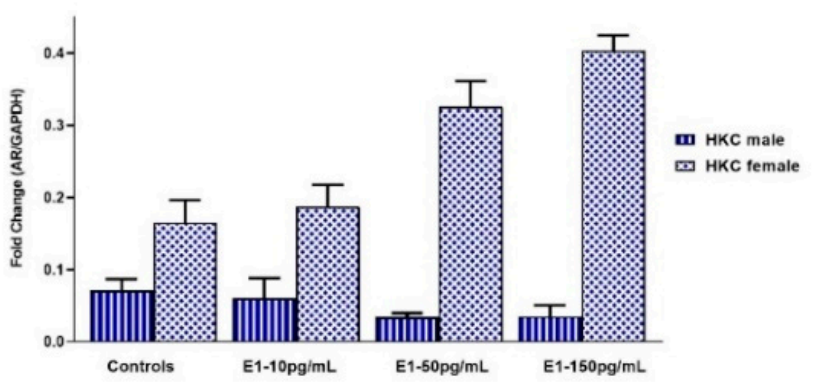

E

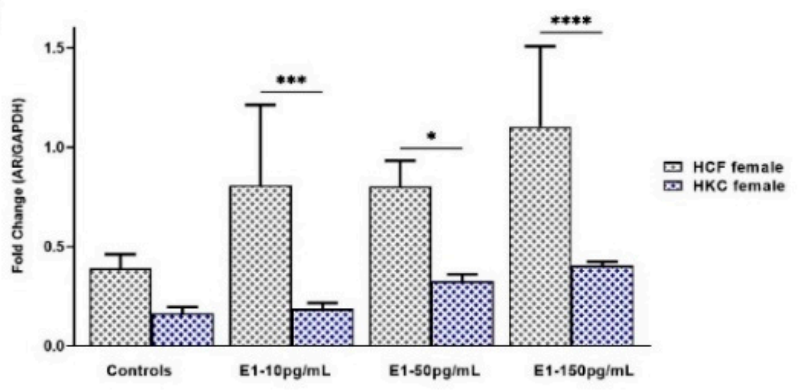

Figure 1. Expression of AR in 3D HCFs and HKCs in response to 10, 50, $150 \mathrm{pg} / \mathrm{mL}$ E1 stimulation for four weeks. (A) Overall AR expression in HCFs and HKCs $(n=6)$. (B) Sex-specific expression of AR in HCFs $(n=3)$. (C) Sex-specific AR expression in HKCs $(n=3)$. (D) Male-specific AR expression in HCFs vs. HKCs $(n=3)$. (E) Female-specific expression of AR in HCFs vs. HKCs. $(n=3) .{ }^{*} p<0.05$, $* * * * 0.001$, and ${ }^{* * * *} p<0.0001$.

\subsubsection{Progesterone Receptor}

The overall PR expression was similar between HCFs and HKCs, with no significant differences. However, 150 pg/mL E1 stimulation showed significantly lower PR expression compared to $10 \mathrm{pg} / \mathrm{mL}$ E1 stimulation, in HKCs (Figure 2A).

Sex-specific PR expression in HCFs showed that females have significantly upregulated PR expression when compared to their male counterparts both in controls and all E1 concentrations tested (Figure 2B). Conversely, there were no significant differences in sex-specific PR expression in HKCs regardless of E1 stimulation (Figure 2C).

When HCF males were compared to HKC males for PR expression, no significant differences were observed (Figure 2D). However, HCF females showed significantly higher AR expression when compared to HKC females in controls and $50 \mathrm{pg} / \mathrm{mL}$ and $150 \mathrm{pg} / \mathrm{mL}$ of E1 stimulation (Figure 2E). 


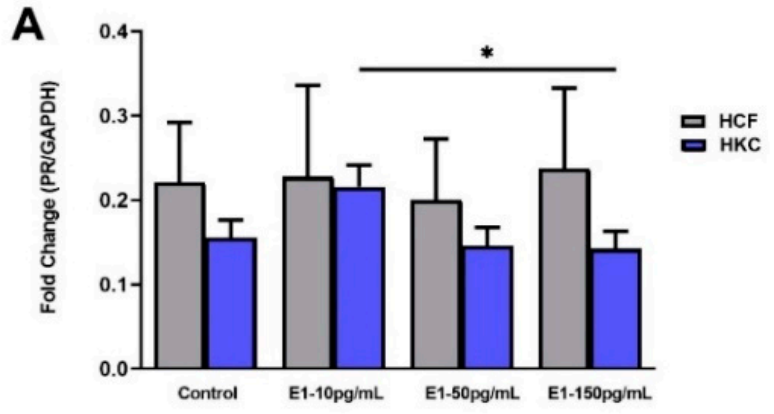

B

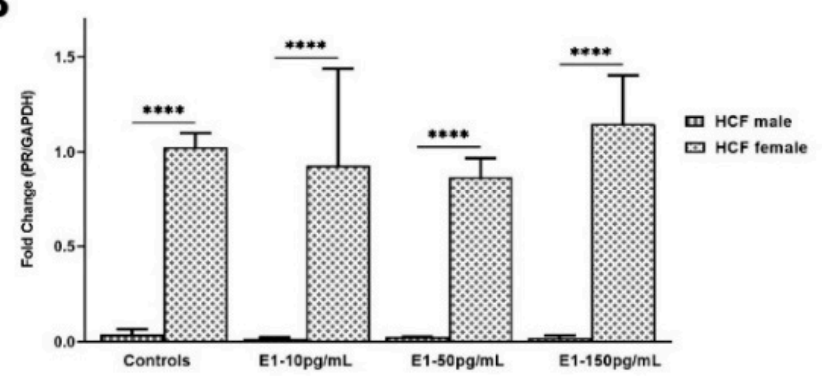

D

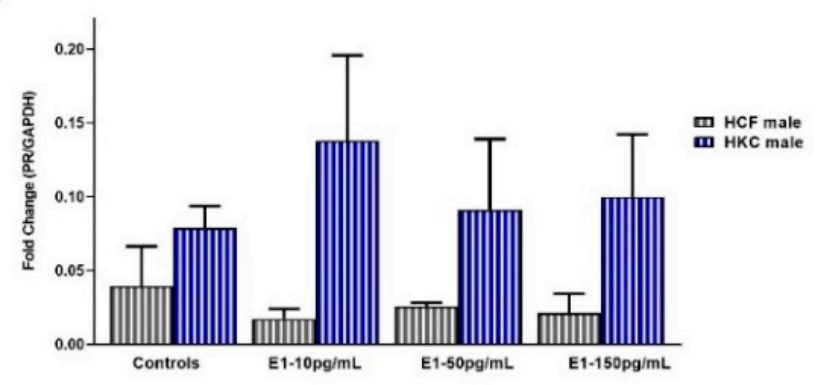

C

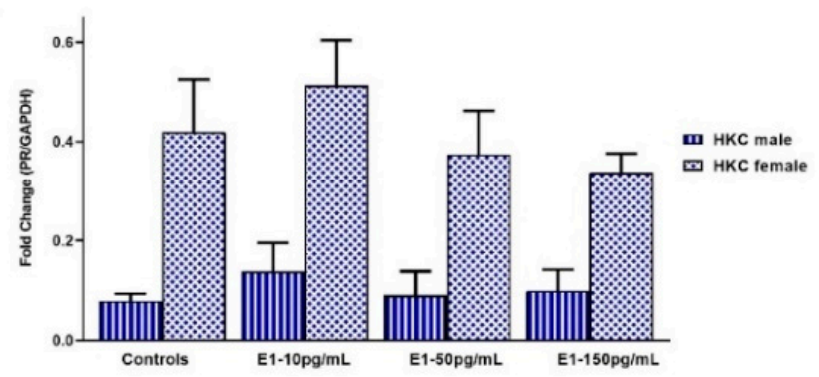

E

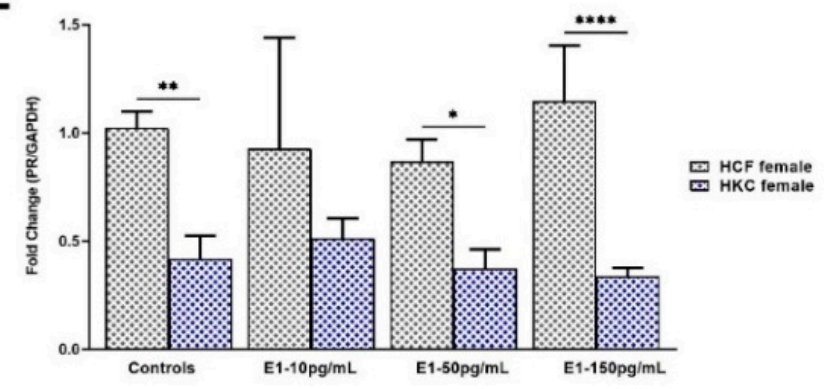

Figure 2. Expression of PR in 3D HCFs and HKCs in response to 10, 50, $150 \mathrm{pg} / \mathrm{mL}$ E1 stimulation for four weeks. (A) Overall PR expression in HCFs and HKCs $(n=6)$. (B) Sex-specific expression of PR in HCFs $(n=3)$. (C) Sex-specific PR expression in HKCs $(n=3)$. (D) Male-specific PR expression in HCFs vs. HKCs $(n=3)$. (E) Female-specific expression of PR in HCFs vs. HKCs $(n=3) .{ }^{*} p<0.05$, ** $p<0.01$, and ${ }^{* * *} p<0.0001$.

\subsubsection{Estrogen Receptor Alpha}

The overall expression of ER $\alpha$ in HCFs and HKCs showed no statistical differences. However, HCFs stimulated with $50 \mathrm{pg} / \mathrm{mL}$ of E1 showed significant upregulation in ER $\alpha$ expression when compared to HCF controls (Figure 3A). No significant differences were observed between HCFs and HKCs when stimulated with E1.

When comparing sex-specific ER $\alpha$ expression in HCFs, females showed significantly higher expression than males under all E1 concentrations tested (Figure 3B). In addition, the expression of ER $\alpha$ in HCF females was significantly upregulated with $50 \mathrm{pg} / \mathrm{mL}$ and $150 \mathrm{pg} / \mathrm{mL}$ of E1 when compared to HCF female controls. Sex-specific ER $\alpha$ expression in HKCs showed significant upregulation with $50 \mathrm{pg} / \mathrm{mL}$ of E1 in females compared to their male counterparts (Figure 3C).

There were no significant differences in ER $\alpha$ expression when comparing HCF males with HKC males (Figure 3D). However, ER $\alpha$ expression in HCF females was significantly upregulated compared to HKC females, when stimulated with $150 \mathrm{pg} / \mathrm{mL}$ of E1 (Figure 3E). 


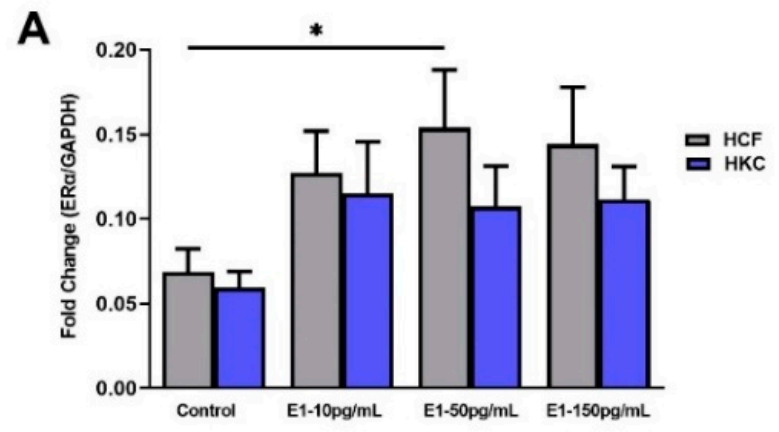

B

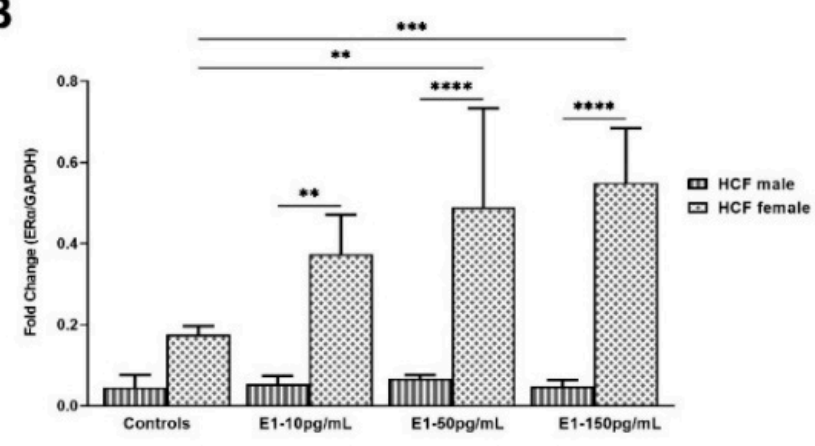

D

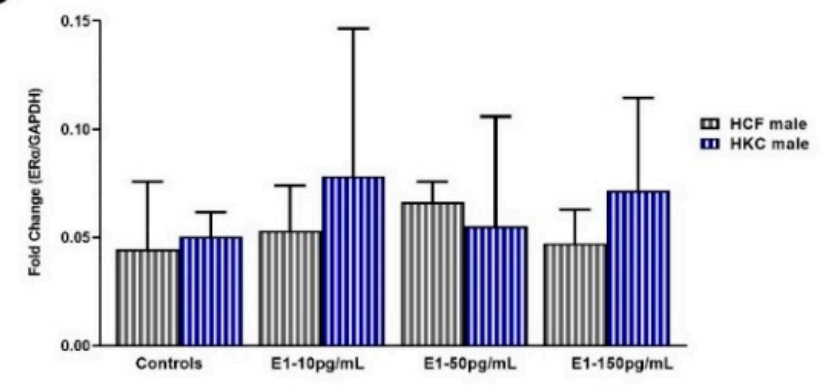

C

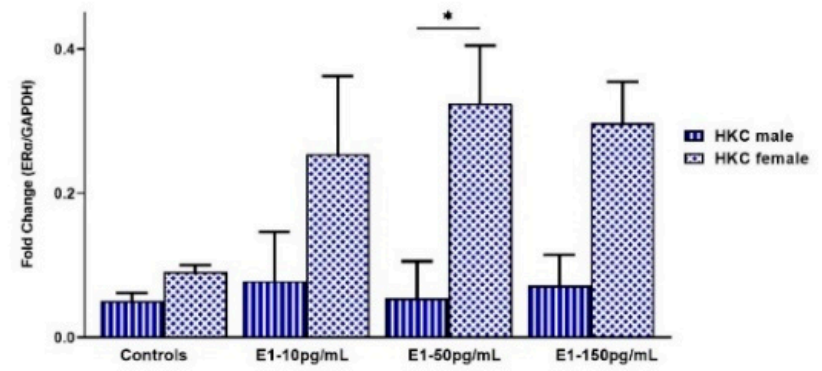

E

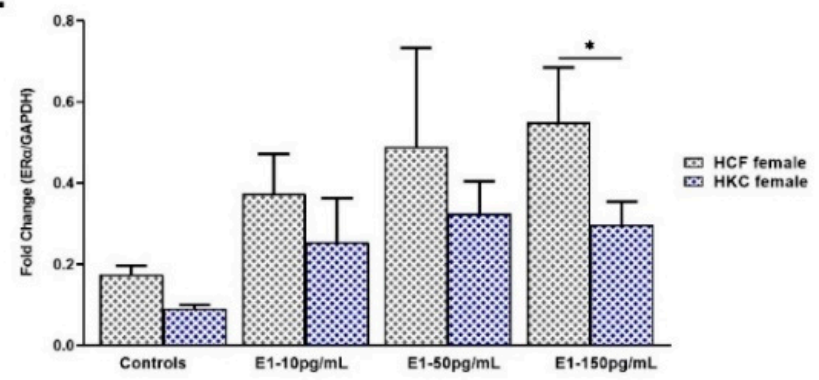

Figure 3. Expression of ER $\alpha$ in 3D HCFs and HKCs in response to 10, 50, $150 \mathrm{pg} / \mathrm{mL}$ E1 stimulation for four weeks. (A) Overall ER $\alpha$ expression in HCFs and HKCs $(n=6)$. (B) Sex-specific expression of ER $\alpha$ in HCFs $(n=3)$. (C) Sex-specific ER $\alpha$ expression in HKCs $(n=3)$. (D) Male-specific ER $\alpha$ expression in HCFs vs. HKCs $(n=3)$. (E) Female-specific expression of ER $\alpha$ in HCFs vs. HKCs. ${ }^{*} p<0.05,{ }^{* *} p<0.01,{ }^{* * *} p<0.001$, and ${ }^{* * *} p<0.0001$.

\subsubsection{Estrogen Receptor Beta}

The overall ER $\beta$ expression in HCFs was significantly upregulated compared to HKCs when stimulated with $50 \mathrm{pg} / \mathrm{mL}$ and $150 \mathrm{pg} / \mathrm{mL}$ of E1 (Figure $4 \mathrm{~A}$ ). In addition, HCF controls showed upregulated ER $\beta$ expression compared to HCFs under all E1 concentrations tested (Figure 4A). Similarly, ER $\beta$ expression in HKC controls was significantly upregulated compared to E1-stimulated HKCs, independent of the concentration (Figure 4A).

When comparing sex-specific ER $\beta$ expression in HCFs, females showed significant upregulation compared to males, for controls and under all E1 concentrations tested (Figure 4B). Expression of ER $\beta$ in HKC males was downregulated significantly with $10 \mathrm{pg} / \mathrm{mL}, 50 \mathrm{pg} / \mathrm{mL}$, and $150 \mathrm{pg} / \mathrm{mL}$ of E1, compared to HKC male controls. We also found that HCF females' ER $\beta$ expression was downregulated with $150 \mathrm{pg} / \mathrm{mL}$ E1 stimulation compared to HKC female controls. Regarding sex-specific ER $\beta$ expression in HKCs, $\mathrm{ER} \beta$ expression was significantly upregulated in females compared to males under all E1 concentrations (Figure $4 \mathrm{C}$ ). Interestingly, ER $\beta$ expression was significantly downregulated in HKC males under all E1 concentrations compared to controls. 
When HCF males were compared to HKC males for ER $\beta$ expression, no significant differences were identified (Figure 4D). In addition, E1 stimulation did not show significant differences in ER $\beta$ expression between HCFs males and HKCs males (Figure 4D). On the other hand, ER $\beta$ expression was significantly upregulated in HCF female controls than HKC female controls (Figure 4E).

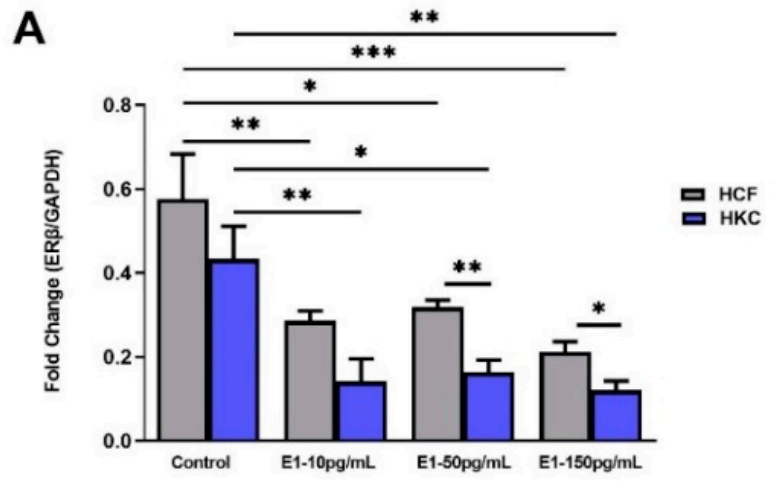

B

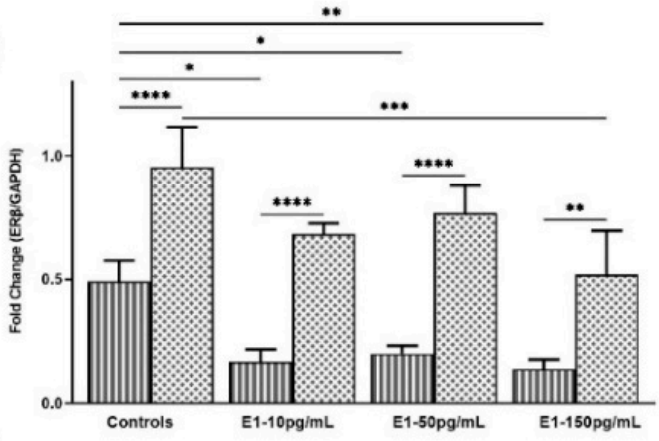

D

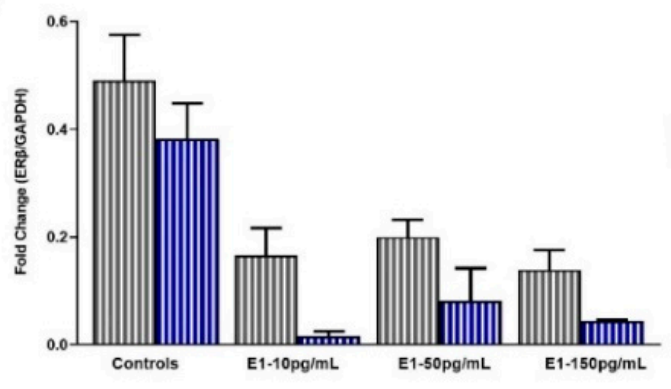

C

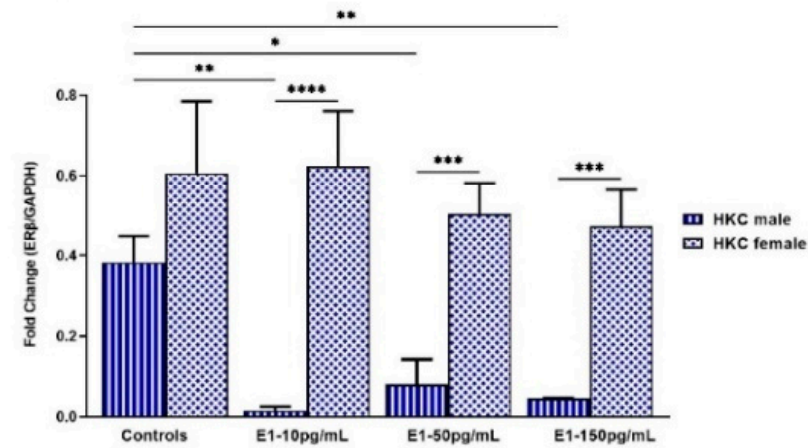

E

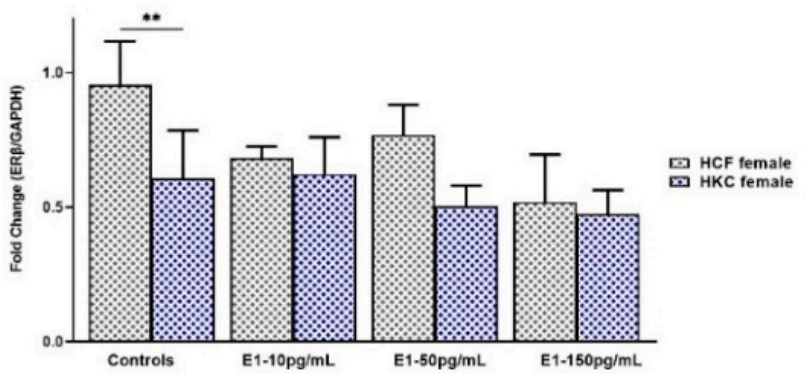

Figure 4. Expression of ER $\beta$ in 3D HCFs and HKCs in response to 10, 50, $150 \mathrm{pg} / \mathrm{mL}$ E1 stimulation for four weeks. (A) Overall ER $\beta$ expression in HCFs and HKCs $(n=6)$. (B) Sex-specific expression of ER $\beta$ in HCFs $(n=3)$. (C) Sex-specific ER $\beta$ expression in HKCs $(n=3)$. (D) Male-specific ER $\beta$ expression in HCFs vs. HKCs $(n=3)$. (E) Female-specific expression of ER $\beta$ in HCFs vs. HKCs $(n=3)$. ${ }^{*} p<0.05,{ }^{* *} p<0.01, * * * p<0.001$, and ${ }^{* * * *} p<0.0001$.

\subsection{Impact of E3 on Sex Hormone Receptors}

Protein expression was investigated for $\mathrm{AR}, \mathrm{PR}, \mathrm{ER} \alpha$, and $\mathrm{ER} \beta$ in 3D HCFs and HKCs constructs at four weeks with or without E3 stimulation $(2,15$, and $30 \mathrm{ng} / \mathrm{mL})$. Findings were also stratified by sex in both HCFs and HKCs.

\subsubsection{Androgen Receptor}

When comparing overall AR expression between HCFs and HKCs, HCF controls showed significant upregulation compared to HKC controls (Figure 5A). In addition, $2 \mathrm{ng} / \mathrm{mL}$ E3 stimulation led to significant AR downregulation in HCFs compared to controls. Furthermore, AR expression in HKCs was unaffected by E3 stimulation (Figure 5A). 
In terms of sex-specific AR expression in HCFs, females showed significantly upregulated expression compared to males in all E3 concentrations tested (Figure $5 \mathrm{~B}$ ). The expression of AR in HCF males was downregulated significantly with $15 \mathrm{ng} / \mathrm{mL}$ and $30 \mathrm{ng} / \mathrm{mL}$ of E3, compared to HCF male controls. Contrastingly, HCF females showed downregulated AR expression with $2 \mathrm{ng} / \mathrm{mL}$, but no changes with $15 \mathrm{ng} / \mathrm{mL}$ or $30 \mathrm{ng} / \mathrm{mL}$ E3 stimulation. HCF females stimulated with $2 \mathrm{ng} / \mathrm{mL}$ of E3 have the lowest AR expression compared to the other conditions, including controls (Figure 5B). Regarding sex-specific AR expression in $\mathrm{HKCs}$, male controls showed significantly downregulated expression than female controls (Figure 5C). Interestingly, AR expression in HKC males was independent of E3 stimulation; whereas, in HKC females, it was only modulated at $30 \mathrm{ng} / \mathrm{mL}$.

Intriguingly, when comparing HCF and HKC males for AR expression, no significant differences were identified (Figure 5D). However, AR expression was significantly downregulated in HKC females compared to HCF females in controls and under all E3 concentrations tested (Figure 5E).
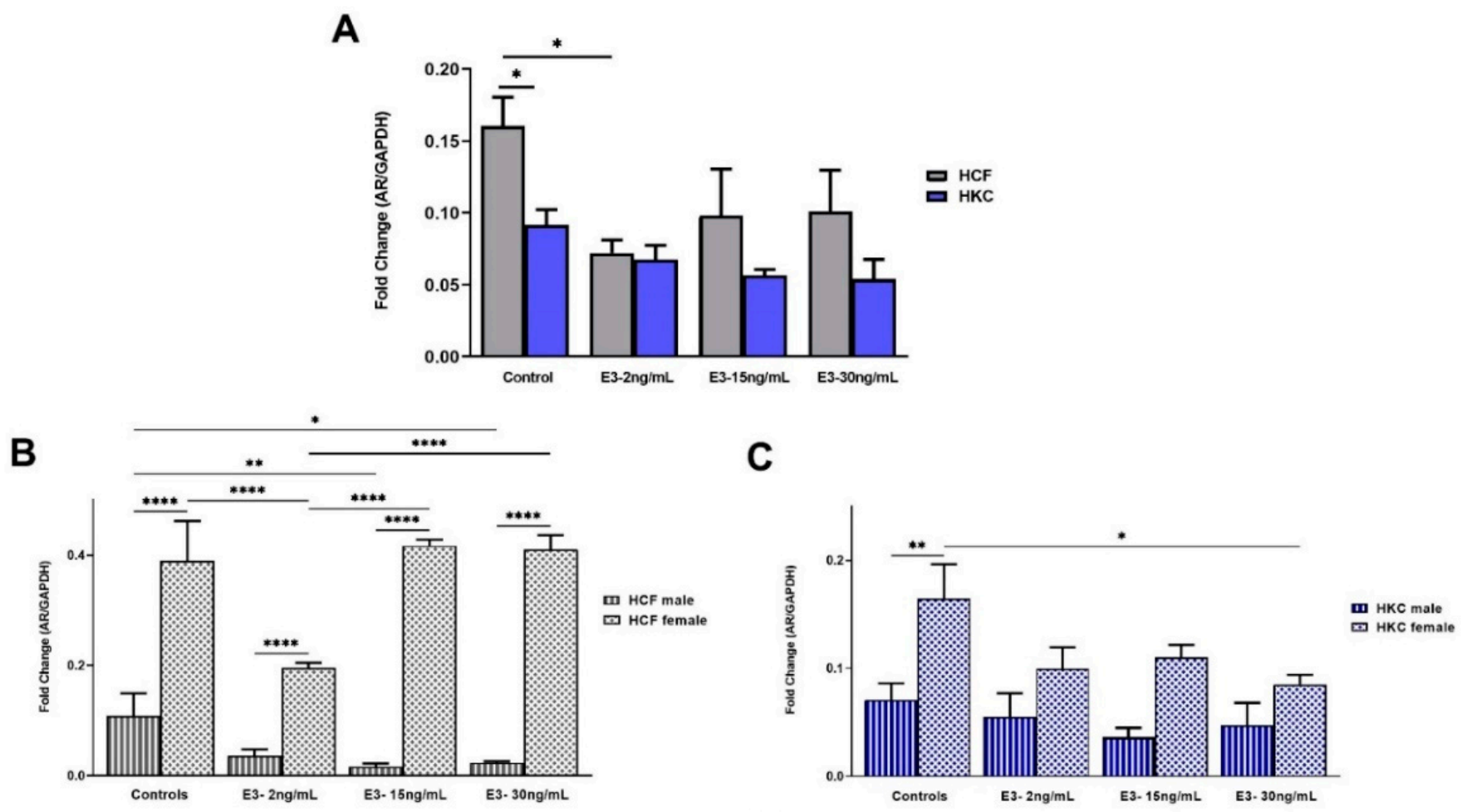

D

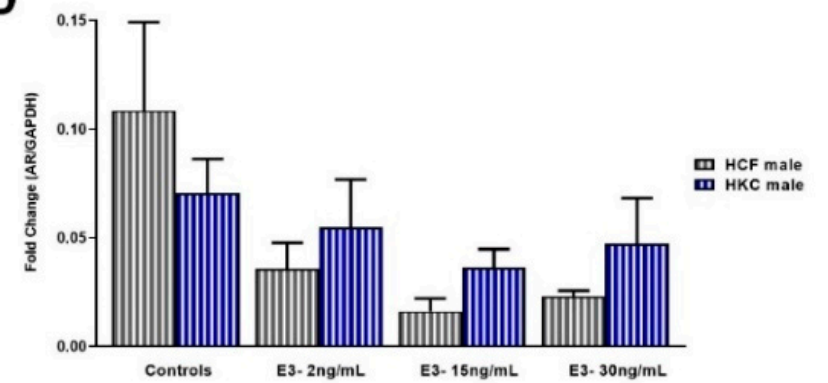

E

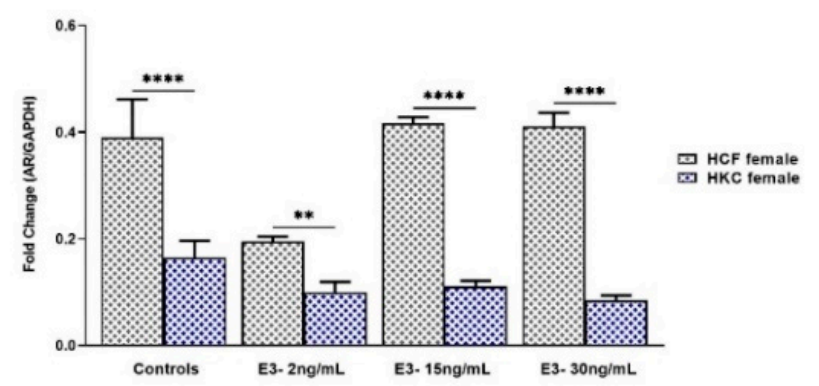

Figure 5. Expression of AR in 3D HCFs and HKCs in response to 2, 15, $30 \mathrm{ng} / \mathrm{mL}$ E3 stimulation for four weeks. (A) Overall AR expression in HKCs and HKCs $(n=6)$. (B) Sex-specific expression of AR in HCFs $(n=3)$. (C) Sex-specific AR expression in HKCs $(n=3)$. (D) Male-specific AR expression in HCFs vs. HKCs $(n=3)$. (E) Female-specific expression of AR in HCFs vs. HKCs. ${ }^{*} p<0.05,{ }^{* *} p<0.01$, and ${ }^{* * * *} p<0.0001$. 


\subsubsection{Progesterone Receptor}

The overall PR expression between HCFs and HKCs showed no significant differences under all E3 concentrations tested or controls (Figure 6A).

There are substantial differences in sex-specific PR expression in HCFs, where females showed significantly upregulated expression compared to males in controls and under all E3 concentrations tested (Figure 6B). In addition, expression of PR was significantly downregulated for HCF females in all E3 concentrations compared to HCF female controls. In terms of sex-specific PR expression in HKCs, male controls and $30 \mathrm{ng} / \mathrm{mL}$ E3 showed significant downregulation when compared to their female counterparts (Figure 6C). In addition, a $2 \mathrm{ng} / \mathrm{mL}$ E3 stimulation led to significant PR downregulation in HKC females compared to controls and $30 \mathrm{ng} / \mathrm{mL}$ E3.

No significant differences in PR expression were observed when comparing HCF and HKC males, regardless of E3 concentrations tested (Figure 6D). On the other hand, HCF females showed significant upregulation of PR expression compared to HKC females in controls and all E3 concentrations tested (Figure 6E).

A

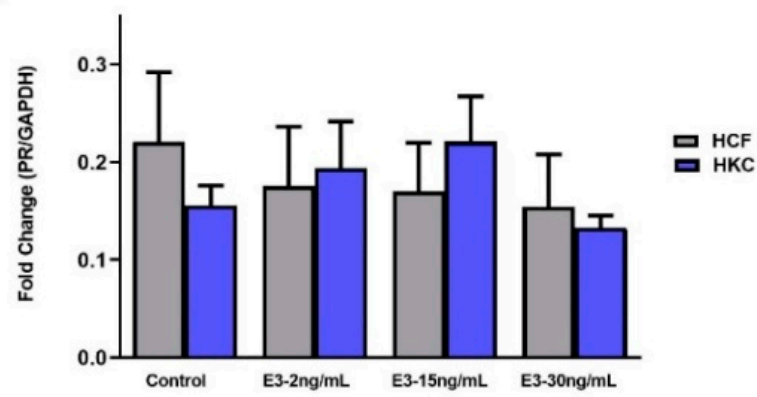

B

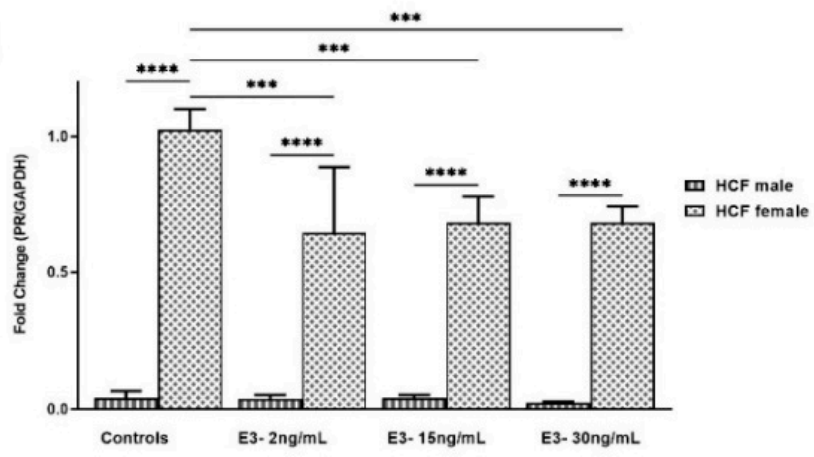

D

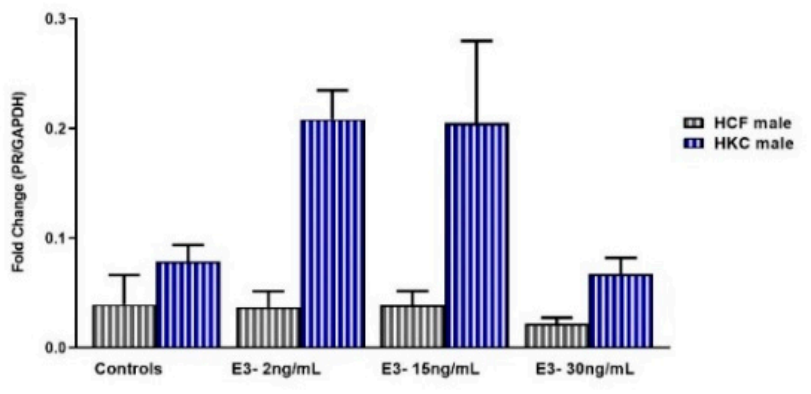

C

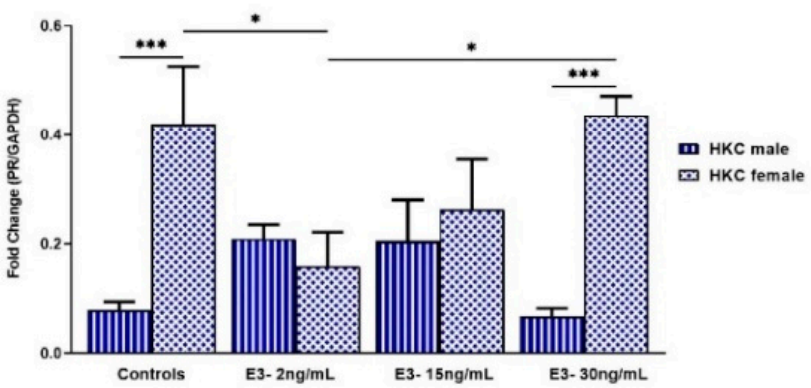

E

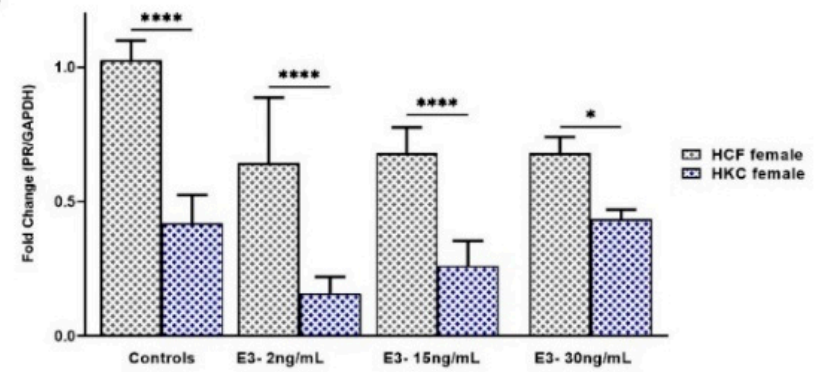

Figure 6. Expression of PR in 3D HCFs and HKCs in response to 2, 15, $30 \mathrm{ng} / \mathrm{mL}$ E3 stimulation for four weeks. (A) Overall PR expression in HCFs and HKCs $(n=6)$. (B) Sex-specific expression of PR in HCFs $(n=3)$ (C) Sex-specific PR expression in HKCs. (D) Male-specific PR expression in HCFs vs. HKCs. (E) Female-specific expression of PR in HCFs vs. HKCs. ${ }^{*} p<0.05,{ }^{* * *} p<0.001$, and ***** $p<0.0001$. 


\subsubsection{Estrogen Receptor Alpha}

The overall ER $\alpha$ expression showed significant upregulation in HCFs stimulated with $15 \mathrm{ng} / \mathrm{mL}$ and $30 \mathrm{ng} / \mathrm{mL}$ of E3 when compared to controls (Figure 7A). In addition, HKCs showed significant upregulation of ER $\alpha$ when stimulated with all concentrations of E3 compared to controls.

When comparing sex-specific ER $\alpha$ expression in HCFs, males showed significantly downregulated expression than females, when stimulated with $15 \mathrm{ng} / \mathrm{mL}$ of E3 (Figure 7B). In terms of sex-specific ER $\alpha$ expression in $\mathrm{HKC}$, females showed significant upregulation compared to males under all E3 concentrations (Figure 7C). HKC female controls and stimulated with $2 \mathrm{ng} / \mathrm{mL}$ of E3 showed significant ER $\alpha$ downregulation compared to $15 \mathrm{ng} / \mathrm{mL}$ and $30 \mathrm{ng} / \mathrm{mL}$ E3s. In addition, $15 \mathrm{ng} / \mathrm{mL}$ E3 led to significant ER $\alpha$ downregulation compared to $30 \mathrm{ng} / \mathrm{mL}$ E3 in HKC females.
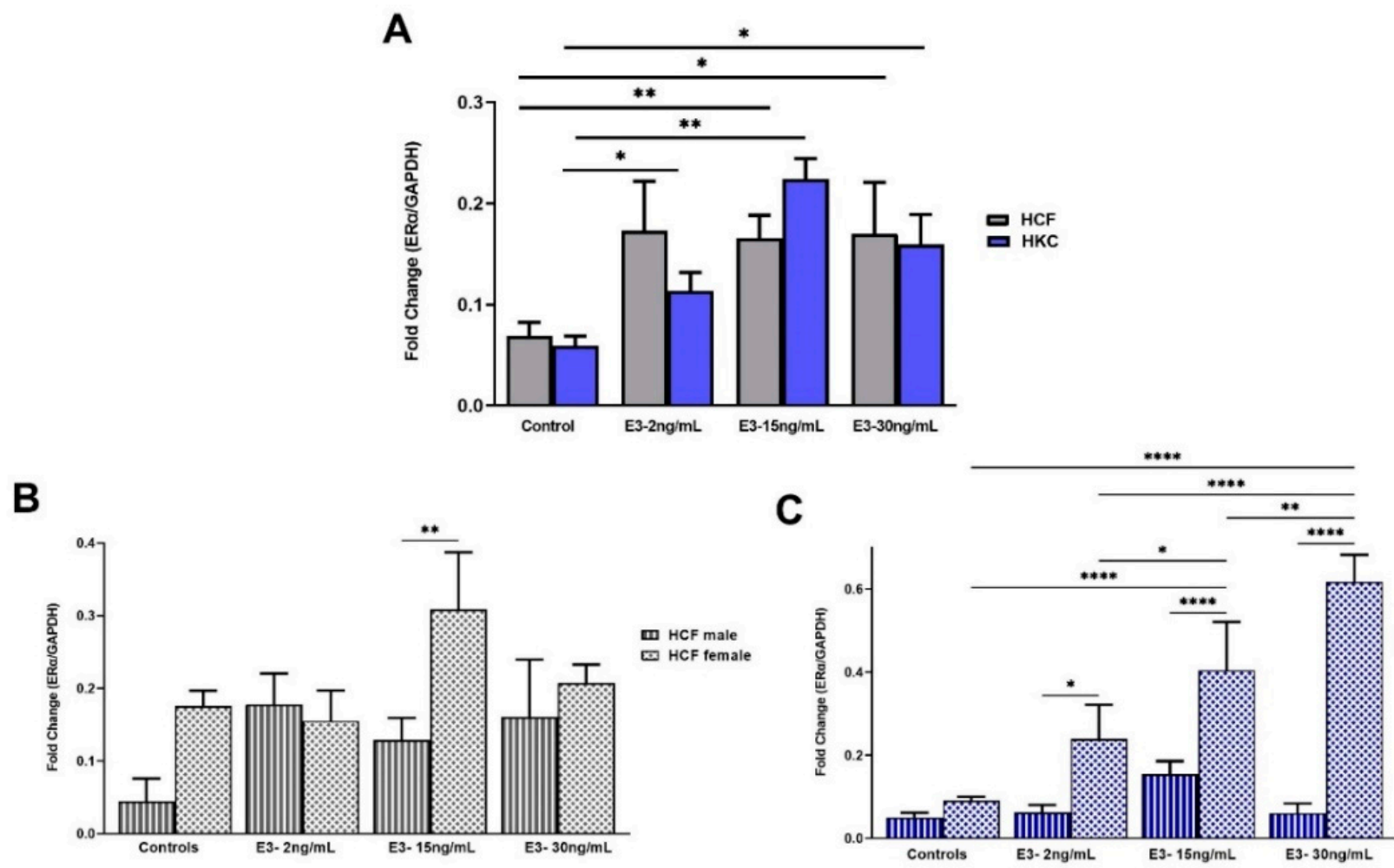

D

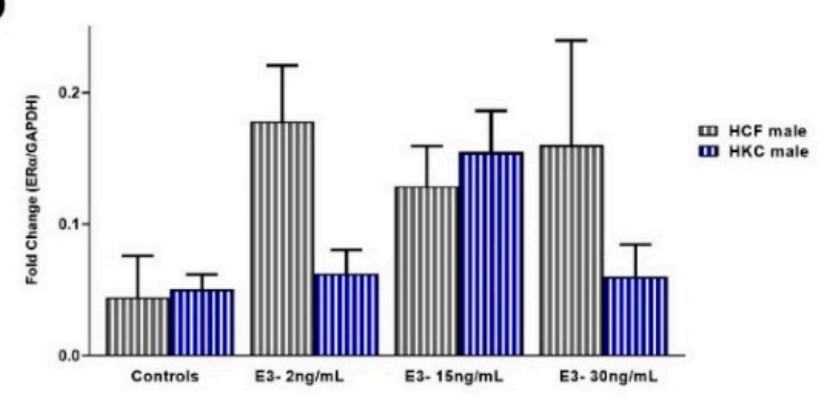

E

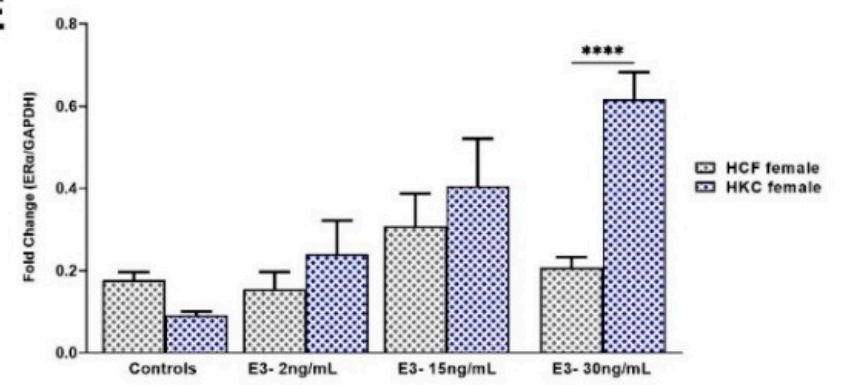

Figure 7. Expression of ER $\alpha$ in 3D HCFs and HKCs in response to 2, 15, $30 \mathrm{ng} / \mathrm{mL}$ E3 stimulation for four weeks. (A) Overall ER $\alpha$ expression in HCFs and HKCs $(n=6)$. (B) Sex-specific expression of ER $\alpha$ in HCFs $(n=3)$. (C) Sex-specific ER $\alpha$ expression in HKCs $(n=3)$. (D) Male-specific ER $\alpha$ expression in HCFs vs. HKCs $(n=3)$. (E) Female-specific expression of ER $\alpha$ in HCFs vs. HKCs $(n=3)$. ${ }^{*} p<0.05,{ }^{* *} p<0.01$, and ${ }^{* * * *} p<0.0001$.

When comparing HCF to HKC males for ER $\alpha$ expression, no significant differences were found, regardless of E3 stimulation (Figure 7D). Contrastingly, a $30 \mathrm{ng} / \mathrm{mL}$ E3 stimu- 
lation led to significant ER $\alpha$ downregulation in HCF females compared to HKC females (Figure 7E).

\subsubsection{Estrogen Receptor Beta}

The overall ER $\beta$ expression showed no significant differences between HCFs and HKCs (Figure 8A). However, HKC controls showed significant downregulation of ER $\beta$ expression compared to HKCs stimulated with $30 \mathrm{ng} / \mathrm{mL}$ of E3.

Regarding sex-specific ER $\beta$ expression in HCFs, male controls showed significantly lower expression than female controls (Figure 8B). In addition, HCF females under all E3 concentrations showed significant ER $\beta$ downregulation compared to controls. In terms of sex-specific ER $\beta$ expression findings in HKCs, males showed downregulated ER $\beta$ expression following $15 \mathrm{ng} / \mathrm{mL}$ E3 stimulation when compared to male controls (Figure $8 \mathrm{C}$ ). In addition, $\mathrm{HKC}$ females showed significant ER $\beta$ upregulation compared to HKC males, in all E3 concentrations tested.

When comparing HCF and HKC males for ER $\beta$ expression, no significant differences were noted (Figure 8D). However, HCF female controls showed significant upregulation of ER $\beta$ compared to HKC females (Figure 8E). ER $\beta$ expression in HCF females with $2 \mathrm{ng} / \mathrm{mL}$ of E3 stimulation showed significant downregulation compared to HKC counterparts.

A

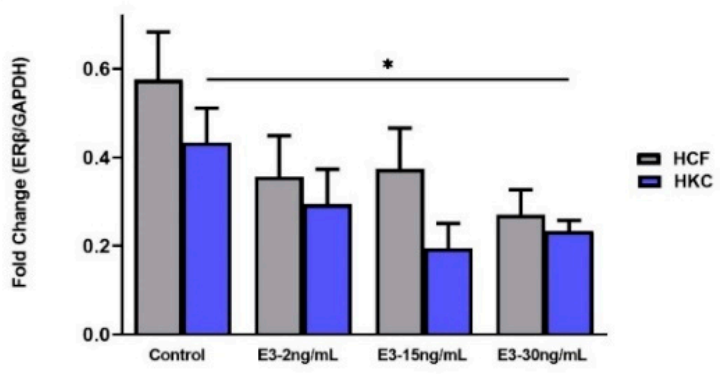

B

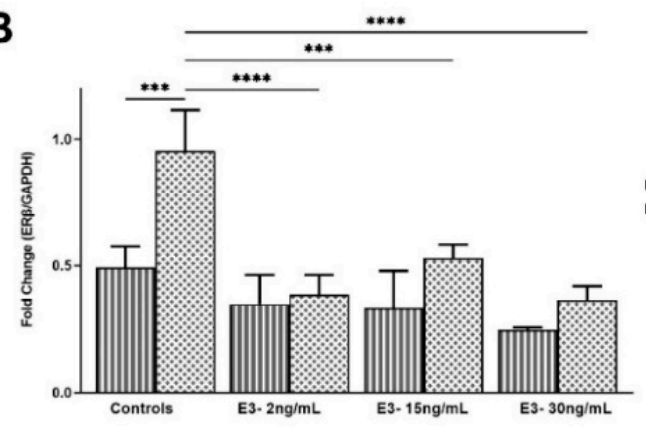

D

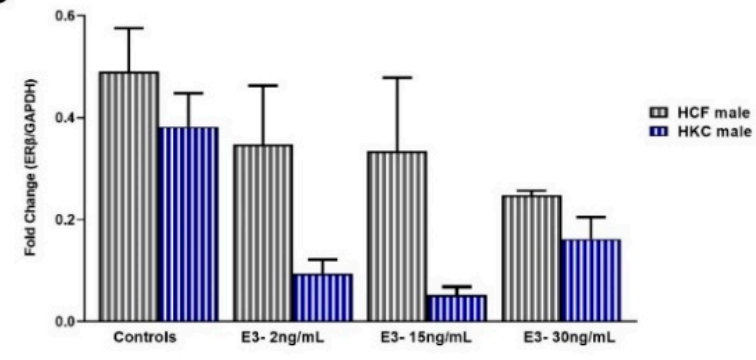

C

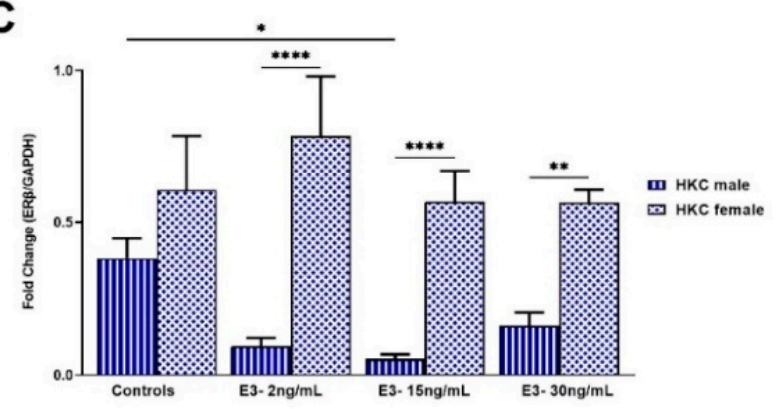

E

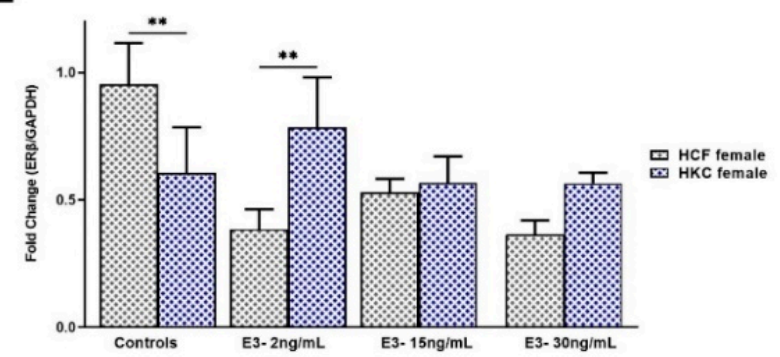

Figure 8. Expression of ER $\beta$ in 3D HCFs and HKCs in response to 2, 15, $30 \mathrm{ng} / \mathrm{mL}$ E3 stimulation for four weeks. (A) Overall ER $\beta$ expression in HCFs and HKCs $(n=6)$. (B) Sex-specific expression of ER $\beta$ in HCFs $(n=3)$. (C) Sex-specific ER $\beta$ expression in HKCs $(n=3)$. (D) Male-specific ER $\beta$ expression in HCFs vs. HKCs $(n=3)$. (E) Female-specific expression of ER $\beta$ in HCFs vs. HKCs $(n=3)$. ${ }^{*} p<0.05,{ }^{* *} p<0.01,{ }^{* * *} p<0.001$, and ${ }^{* * *} p<0.0001$. 


\section{Discussion}

KC presents during puberty $[15,30]$ as hormone levels considerably change and its progression stabilizes during menopause/andropause, as another oscillation of hormone levels happens in life [36]. Hence, hormonal changes significantly contribute to the variations by age and sex in KC occurrences. In addition, KC progression in pregnancy supports the relationship between hormone changes and the human cornea [16,18-20]. Therefore, we advance on a pathogenesis theory that $K C^{\prime}$ 's fluctuating progression during puberty, pregnancy, and menopause is strongly influenced by the effects of hormone levels and their receptors present in the cornea.

In the current study, we investigated the effects of two hormones, E1 and E3, on sex hormone receptors present in the human cornea. The results are summarized in Table 1. Our study reveals that sex hormone receptors in the cornea are impacted by hormone stimulation (E1 and E3), and their expression is sex-dependent. To date, no cellular/molecular studies have demonstrated the effects of sex hormones in the human cornea and whether this dynamic differs between heathy and KCs. Interestingly, studies have shown that estrogen modifies corneal biomechanics in pig corneas $[37,38]$, yet there is no such evidence in human corneas. An animal model studying keratoconus has also shown hormone (androgen) dependency, where corneal changes occurred exclusively in male mice, and when castrated the changes were drastically diminished [39]. In addition, when female mice were simulated with androgen, they showed a similar corneal phenotype as male mice [39].

Table 1. Summary for protein expression results of sex hormone receptors in of HCFs and HKCs stimulated with E1 and E3. $\uparrow=$ upregulation and $\downarrow=$ downregulation

\begin{tabular}{|c|c|c|}
\hline & $\overline{\text { E1 }}$ & E3 \\
\hline$\leftleftarrows$ & $\begin{array}{l}\text { Overall } \uparrow \text { in HCFs compared to HKCs in controls } \\
\text { (Figure } 1 \mathrm{~A} \text { ). } \\
\text { - } \quad \text { in HCF females compared to HCF males in all } \\
\text { concentrations (Figure } 1 \mathrm{~B} \text { ). } \\
\quad \downarrow \text { in HCF females controls compared to HCF females } \\
\text { stimulated with } 150 \mathrm{pg} / \mathrm{mL} \text { (Figure } 1 \mathrm{~B} \text { ). } \\
\quad \uparrow \text { in HCF females compared to HKC females in all } \\
\text { concentrations (Figure 1E). }\end{array}$ & 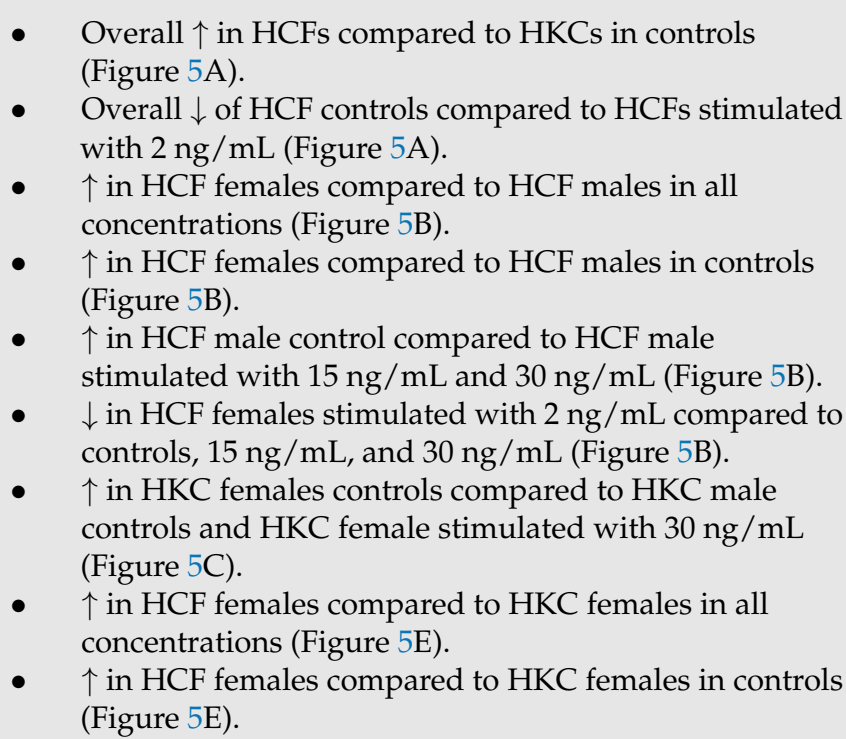 \\
\hline
\end{tabular}


Table 1. Cont.

\begin{tabular}{|c|c|c|}
\hline$\frac{a}{a}$ & 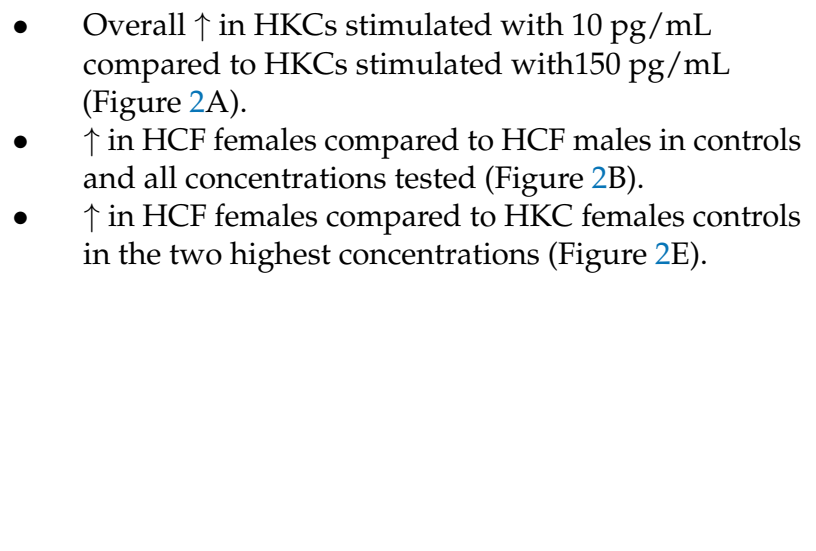 & $\begin{array}{l}\text { - } \quad \uparrow \text { in HCF females compared to HCF males in controls } \\
\text { and all concentrations tested (Figure 6B). } \\
\text { - } \quad \downarrow \text { in HCF females stimulated with all concentrations } \\
\text { compared to HCF female controls (Figure 6B). } \\
\text { - } \quad \text { in HKC female controls and stimulated with } \\
30 \mathrm{ng} / \mathrm{mL} \text { compared to HKC male controls and } \\
\text { simulated with } 30 \mathrm{ng} / \mathrm{mL} \text { (Figure } 6 \mathrm{C} \text { ). } \\
\quad \downarrow \text { in HKC females stimulated with } 2 \mathrm{ng} / \mathrm{mL} \text { compared } \\
\text { to HKC female controls and stimulated with } 30 \mathrm{ng} / \mathrm{mL} \\
\text { (Figure } 6 \mathrm{C} \text { ). } \\
\text { - } \\
\text { in in HCF females compared to HKC females controls } \\
\text { and in the two highest concentrations (Figure } 6 \mathrm{E} \text { ). } \\
\quad \uparrow \text { in HCF females compared to HKC females stimulated } \\
\text { with } 2 \mathrm{ng} / \mathrm{mL} \text { (Figure } 6 \mathrm{E} \text { ). }\end{array}$ \\
\hline$\frac{8}{\tilde{1}}$ & $\begin{array}{l}\text { - } \quad \text { Overall } \downarrow \text { in HCF controls compared to HCF } \\
\text { stimulated with } 50 \mathrm{pg} / \mathrm{mL} \text { (Figure } 3 \mathrm{~A} \text { ). } \\
\text { - } \quad \uparrow \text { in HCF females compared to HCF males } \\
\text { stimulated with } 50 \mathrm{pg} / \mathrm{mL} \text { (Figure 3B). } \\
\text { - } \quad \text { in HCF females compared to HCF males } \\
\text { stimulated with } 10 \text { and } 150 \mathrm{pg} / \mathrm{mL} \text { (Figure } 3 \mathrm{~B} \text { ). } \\
\quad \downarrow \text { in HCF females controls compared to HCF males } \\
\text { stimulated at } 50 \text { and } 150 \mathrm{pg} / \mathrm{mL} \text { (Figure 3B). } \\
\quad \uparrow \text { in HKC females compared to HKC males } \\
\text { - } \quad \text { stimulated at } 50 \mathrm{pg} / \mathrm{mL} \text { (Figure } 3 \mathrm{C} \text { ). } \\
\quad \uparrow \text { in HCF females compared to HKC females } \\
\text { stimulated at } 150 \mathrm{pg} / \mathrm{mL} \text { (Figure } 3 \mathrm{E} \text { ). }\end{array}$ & 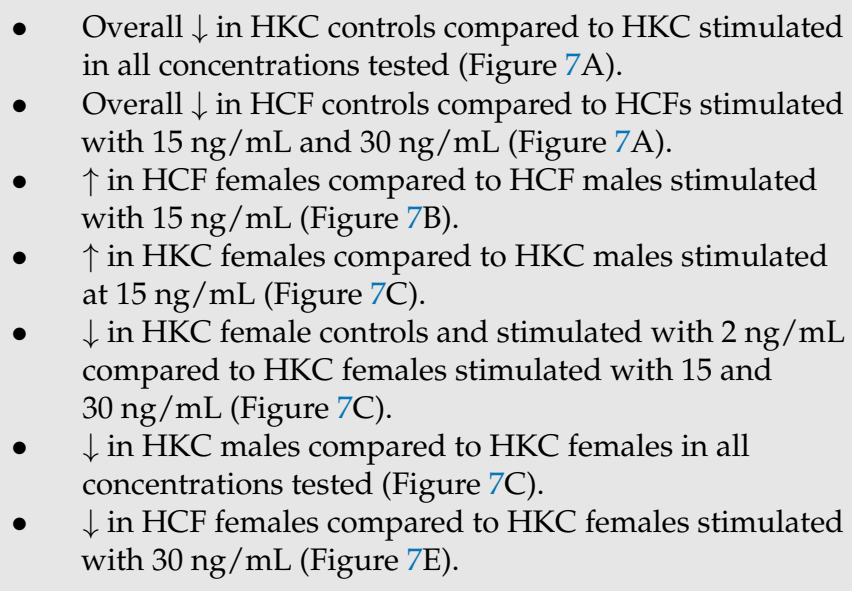 \\
\hline$\frac{0}{\pi}$ & 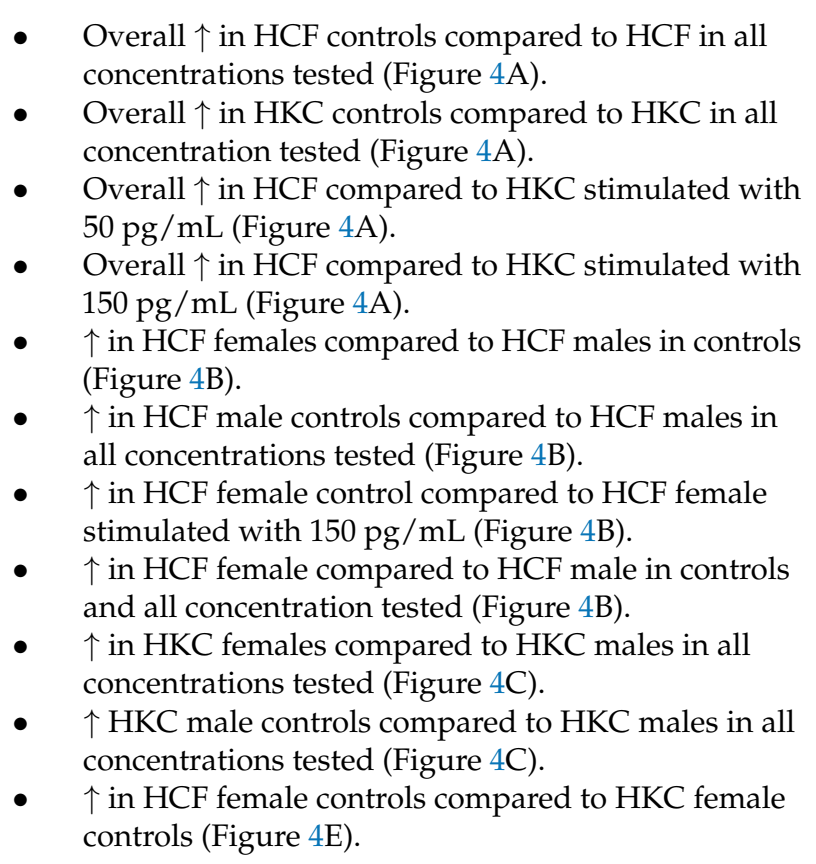 & 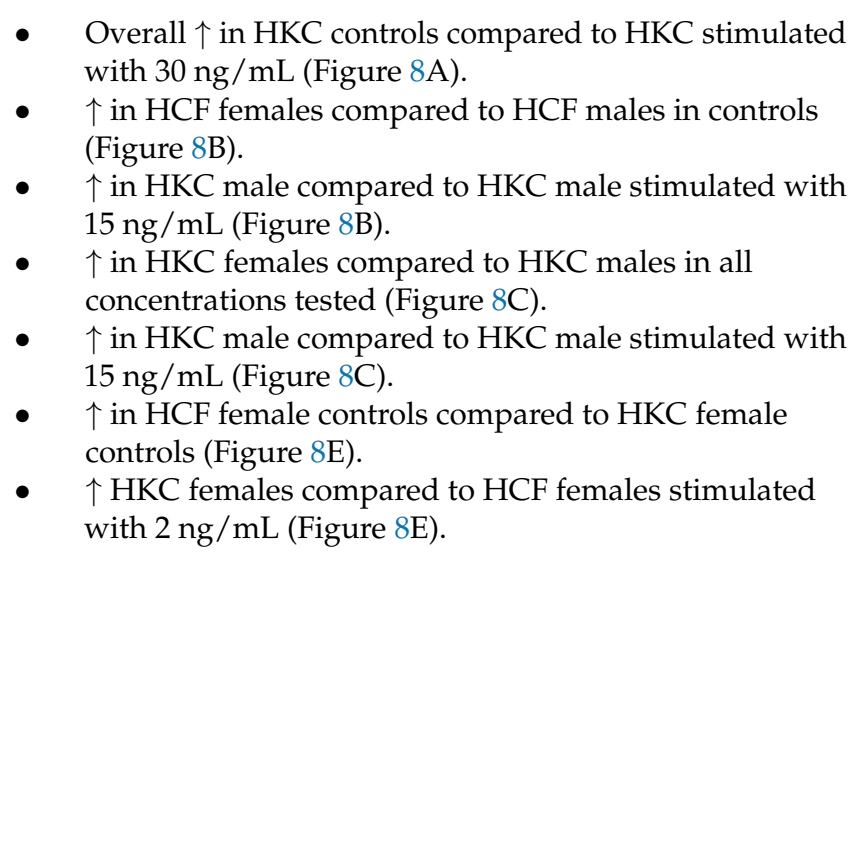 \\
\hline
\end{tabular}


E1 and E3 are estrogens produced by the ovaries in females and by the testes in males. Throughout menopause, E1 levels are predominant in the circulation and are responsible for sexual development, function, and can serve as a repository for estrogen (converting E1 to estrogen) [40,41]. A recent in vitro study showed that estrogen receptors mediated E1 biomechanical action in bone tissue to promote osteoblasts differentiation, which can aid post-menstrual women with osteoporosis [42]. In addition, clinical studies have shown E3 significantly improves bone mineral density in women with post-menopausal osteoporosis [43]. Clinical studies have also shown E3 effectiveness in treating symptomatic vaginal atrophy and abnormal vaginal flora therapy in pre- and post-menopausal women [44].

The physiologic process that happens during menopause has been shown to alter corneal topography in females [26]. Studies have shown that hormone replacement therapy on post-menopausal patients with KC could lead to the progression of KC [45,46]. Our study showed that E1 stimulation activated AR and ER $\alpha$ expression in HCF females compared to HCF males and HKC females (Figure 1B,E). In addition, our results showed E1 stimulation affected $A R, E R \alpha$, and $E R \beta$, with little to no response from PR expression in HCF females A study by Bjerregaard-Olesen has also shown that ER and AR can transactivate by cell culture exposure to sulfated E1, dependent on concentration [47]. Our results not only show similar activation of the receptors for HCF response to E1, but also reveal that the response is female-dependent for $\mathrm{AR}, \mathrm{ER} \alpha$, and $\mathrm{ER} \beta$. It is plausible that $\mathrm{KC}$, in males and females, is altered depending on which sex hormone receptor is modulated.

E3 levels increase progressively throughout pregnancy [48]; thus, there may be a direct association of E3 levels with disease exacerbation in KC. A recent study showed that in vitro fertilization (ivf) treatment increased estrogen levels, leading to the progression of $\mathrm{KC}$ in three patients [49]. Our results showed differences in AR and PR expression modulated by E3 between HCF and HKC females (Figures 5A and 6E). In addition, for HKCs, there was an inverse correlation between E3 modulation overall expression of ER $\alpha$ (increased expression with E3) and ER $\beta$ (decreased expression with E3) (Figures 7A and 8A). In addition, we analyzed the impact of both estrogen stimulations on the overall expression of ER $\alpha$ and ER $\beta$ (Figure 9A,B). The combined estrogen stimulations demonstrated an inverse response between $\mathrm{ER} \alpha$ and $\mathrm{ER} \beta$ compared to controls for both HCF's and HKC's. However, further studies must be performed using an E1 and E3 combination stimulation to identify if the results are actually due to estrogen stimulation.

A

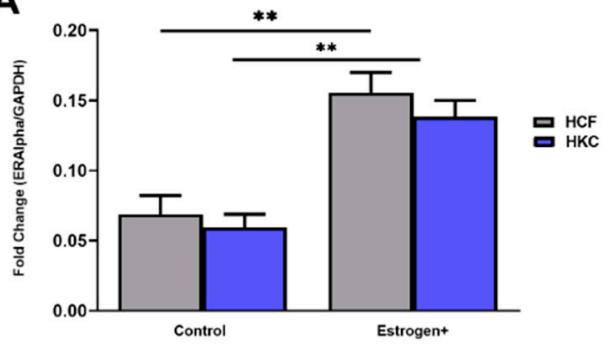

B

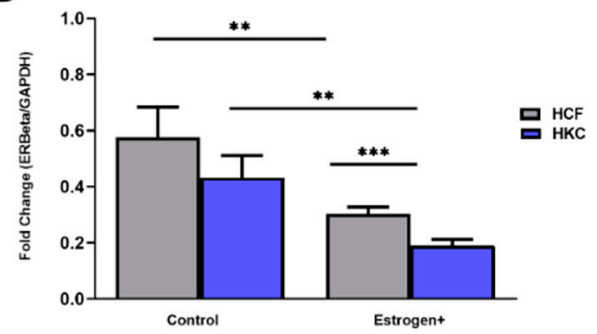

Figure 9. Expression of ER $\alpha$ and ER $\beta$ in 3D HCFs and HKCs in response to estrogen+ (E1 and E3) stimulation for four weeks. (A) Overall ER $\alpha$ expression in HCFs and HKCs $(n=6)$. (B) Overall expression of ER $\beta$ in HCFs and HKCs $(n=6)$. ${ }^{* *} p<0.01$, and ${ }^{* * *} p<0.001$.

It is clear that HKC's sex hormone receptors respond to sex hormones, which may correlate with the response in $\mathrm{KC}^{\prime}$ 's fluctuation in corneal changes observed during puberty, menstrual cycle, pregnancy, and menopause. Previous studies have also reported corneal thickness alterations in different menstrual cycle stages [50-52]. These changes can be attributed to hormone influence on hormonal receptors, significantly causing corneal thickness alterations. Our study revealed E1 and E3 modulation on hormone receptors present in human corneal stromal cells. Although we did not observe morphological changes in 
the cells from E1 and E3 stimulation, in the future, studies on cellular proliferation and toxicity are needed to rule out any adverse effects from all concentrations tested.

Sex hormone receptors, including $A R, P R, E R \alpha$, and $E R \beta$, have not only been identified in the human cornea $[27,53]$ and lacrimal gland $[34,35,54]$ but are also implicated in ocular diseases such as dry eye [55]. A previous study showed that PR expression was inhibited, whereas AR was activated in KC corneas [28]. Additionally, ER $\alpha$ and ER $\beta$ showed similar expression levels in control and KC corneas [28]. Our present study found that E1 and E3 modulated the activation of $\mathrm{AR}, \mathrm{PR}, \mathrm{ER} \alpha$, and $\mathrm{ER} \beta$ in HCF females compared to HCF males. (Figures 1B-8B). Although AR is associated with male reproduction, AR is also essential for female fertility, specifically for ovarian follicle development and full functionality during ovulation [56]. Therefore, $\mathrm{AR}, \mathrm{PR}, \mathrm{ER} \alpha$, and $\mathrm{ER} \beta$, found in human corneas play a role in corneal physiology and may be influenced by any hormones found in fluids surrounding the eye, such as tear fluid. While we investigated the E1 and E3 response in cornea stromal cells from healthy and $\mathrm{KC}$ donors, sex hormone receptors have also been found in the nuclei of corneal epithelial and endothelial cells [27]. It is, therefore, critical that future studies investigate the response, if any, of sex hormone receptors in cornea epithelial and endothelial cells with stimulation of E1 and E3. Such studies will provide a complete picture of the impact of these receptors, in KC.

Additional studies will be needed, including additional donors per sample group in order to delineate the sex differences observed. $\mathrm{KC}$ is a diverse, complicated, and multifactorial disease of the human cornea. Our in vitro studies highlight the importance of sex bias in KC. The topic is certainly worthy of more attention and research studies, given that clinical cases support such a motion. The major limitation of our study is the low number of donor samples, tested per group. Therefore, it is currently unknown how our finding might change in the future when factors such as age, or KC severity are considered. Regardless, our studies are novel and should stimulate further discussions, and scientific discoveries in the field.

Our data showed that hormonal receptors are responsive to E1 and E3; however, the downstream signaling mechanism(s) behind the activation/deactivation and impact of such activity remain unknown. A rather obvious theory/hypothesis would be that E1 and E3 bind to the hormone receptors on cell membranes, thereby causing a signaling cascade that leads to the activation of these receptors. Nonetheless, further research is warranted to investigate if activation/deactivation of sex hormone receptors modulates the human corneal microenvironment. Our findings are novel and support existing clinical reports and case studies on the importance of hormones in KC pathobiology, emphasizing the presence and role of sex hormone receptors in the human cornea. Further studies are necessary to determine how these estrogen-derived hormones can be utilized as therapeutics for KC progression and development.

\section{Materials and Methods}

\subsection{Ethical Approval}

The study adhered to the tenets of the Declaration of Helsinki and was performed with the North Texas Regional Institutional Review Board (IRB) approval (protocol \#2020-031). Written and informed consent was obtained prior to tissue collection, all methods were performed according to federal and institutional guidelines and all human samples were de-identified before analysis. A total of four donor tissues were used including; a healthy female (72 y/o), a healthy male ( 64 y/o), a KC female ( 43 y/o), and a KC male (19 y/o).

\subsection{Corneal Stromal Cells Isolation}

Human corneal stromal cells were isolated from both male and female KC (HKC) and healthy (HCF) corneas. Briefly, corneas were suspended in sterile PBS (Thermo Fisher Scientific, Waltham, MA, USA) to maintain hydration. Using a scalpel blade, one-third of the cornea was removed, saved for protein extraction, and used for future research studies. The rest of the cornea was then scraped using a razor for approximately $10 \mathrm{~s}$ from 
top and bottom to remove the cornea epithelium and endothelium. The corneal stromal explants were then rinsed with sterile PBS and cut into $2 \times 2 \mathrm{~mm}$ pieces. The explant pieces were adhered to a T25 flask by incubation for $45 \mathrm{~min}$ at $37{ }^{\circ} \mathrm{C}$ in $5 \% \mathrm{CO}_{2}$. Finally, corneal stromal explants were incubated with $10 \%$ fetal bovine serum (FBS) (Atlanta Biologicals, Flowery Branch, GA, USA), and 1\% antibiotic/antimycotic (AA) (Life Technologies, Grand Island, NY, USA) in Eagle's Minimum Essential Media (EMEM) (American Type Culture Collection, Manassas, VA, USA) for one week. After the first week, the media was changed every two days for four weeks. Once cells reached $\sim 80 \%$ confluency, they were isolated with trypsin and frozen with cryogenic protection for further processing.

\subsection{Cell Cultures and Stimulations}

Male and female HCFs and HKCs were cultured in T175 flasks until 80\% confluency. Both cell types were counted following trypsinization and sub-cultured at a density of $1 \times 10^{6}$ cells / well in 6-well 3D (transwell) plates (VWR, Radnor, PA, USA) with 10\% FBS, $1 \%$ AA in EMEM. Control constructs were stimulated with EMEM containing 10\% FBS, $1 \%$ AA, and $0.5 \mathrm{mM}$ stable vitamin C (0.5 mM 2-O- $\alpha$-D-glucopyranosyl-L-ascorbic acid, Sigma-Aldrich, St. Louis, MO, USA), as previously reported [57-60]. Constructs were also treated with E1 and E3 at three concentrations each as follows: E1-10 pg/mL, $50 \mathrm{pg} / \mathrm{mL}$, and $150 \mathrm{pg} / \mathrm{mL}$ (E1253, Sigma-Aldrich, St. Louis, MO, USA) and E3-2 ng/mL, $15 \mathrm{ng} / \mathrm{mL}$ and $30 \mathrm{ng} / \mathrm{mL}$ (E9750, Sigma-Aldrich, St. Louis, MO, USA) in EMEM containing 10\% FBS, $1 \% \mathrm{AA}$, and $0.5 \mathrm{mM}$ stable vitamin $\mathrm{C}$. All constructs were cultured for four weeks before further analysis.

\subsection{Protein Extraction and Quantification}

Protein was extracted from each construct using $100 \mu \mathrm{L}$ of $1 \mathrm{X}$ radioimmunoprecipitation assay buffer and a protease inhibitor lysis cocktail (RIPA, Sigma-Aldrich, St. Louis, MO, USA). In brief, $100 \mu \mathrm{L}$ of lysis cocktail was added to each tube and kept on ice throughout the procedure. Media was then aspirated and discarded, followed by a $1 \mathrm{~mL}$ cold PBS wash, twice for each construct. All samples were incubated in an ice bucket at $4{ }^{\circ} \mathrm{C}$ for $30 \mathrm{~min}$ in the lysis cocktail. The cell lysates were centrifuged at $4{ }^{\circ} \mathrm{C}$ for $15 \mathrm{~min}$ at $12,000 \mathrm{rpm}$, and the supernatant was carefully collected into a new tube for Western blot analysis.

Protein samples were quantified using Pierce ${ }^{\mathrm{TM}}$ BCA Protein Assay Kit (Thermo Fisher Scientific, Waltham, MA USA). In brief, $10 \mu \mathrm{L}$ of Pierce ${ }^{\mathrm{TM}}$ Bovine Serum Albumin Standards (Thermo Fisher Scientific, Waltham, MA, USA) were added to a Corning ${ }^{\mathrm{TM}}$ Costar $^{\mathrm{TM}}$ 96well-plate (Thermo Fisher Scientific, Waltham, MA, USA). Samples were then vortexed and $10 \mu \mathrm{L}$ were added to the 96-well plate. Finally, $200 \mu \mathrm{L}$ of Pierce ${ }^{\mathrm{TM}} \mathrm{BCA}$ reagent A and reagent $\mathrm{B}$ working solution was added to each well, mixed with shaker for $30 \mathrm{~s}$, and incubated at $37^{\circ} \mathrm{C}$ with $5.0 \% \mathrm{CO}_{2}$ for $30 \mathrm{~min}$. After incubation, absorbance was measured using the BioTek EPOCH2 microplate reader (BioTek, Winooski, VT, USA) set at $562 \mathrm{~nm}$. BioTek software was used to calculate results by plotting the absorbance values using linear regression to the standards.

\subsection{Western Blot Assay}

Normalized protein samples were denatured, added into Novex 4-20\% Tris-glycine mini Wedge 12-well gels (Invitrogen, ThermoFisher Scientific, Waltham, MA, USA), then run via electrophoresis at 225 volts for 30 -min and transferred into nitrocellulose membranes using the Invitrogen iBlot 2 Dry Blotting system at setting P0.

The membranes were then blocked in 5\% milk with Trans buffered saline with tween 20 (TBST) and incubated at room temperature on a shaker for one hour. Next, the membranes were incubated overnight on a rocker at $4{ }^{\circ} \mathrm{C}$ in the following rabbit polyclonal antibodies: AR (ab133273, Abcam, Cambridge, MA, USA), PR (ab191138, Abcam, Cambridge, MA, USA), ER $\alpha$ (ab75635, Abcam, Cambridge, MA, USA), and ER $\beta$ (ab3576, Abcam, Cambridge, MA, USA) at a 1:250 dilution or mouse monoclonal GAPDH antibody conjugated with AlexaFluor 680 at a 1:2000 dilution (ab184095, Abcam, Cambridge, MA, USA). The mem- 
branes were washed three times for five minutes with TBST and incubated with donkey anti-rabbit IgG (H+L) AlexaFluor 568 antibody (ab175470, Abcam, Cambridge, MA, USA) at a 1:2000 dilution for $1 \mathrm{~h}$ on a rocker at room temperature. After washing, all membranes were imaged using the iBright FL 15000 imaging system (ThermoFisher Scientific, Waltham, MA, USA). Results were analyzed using iBright analysis software (ThermoFisher Scientific, Waltham, MA, USA) and results were normalized to the expression of GAPDH housekeeping.

\subsection{Statistical Analysis}

GraphPad Prism 7.0 was used for performing all statistical analyses (GraphPad Software, Inc., La Jolla, CA, USA). Data were analyzed using one-way analysis of variance (ANOVA) and $t$-test where necessary, a value of $p<0.05$ was considered statistically significant.

Author Contributions: Conceptualization, D.K. and P.E.; methodology, P.E.; software, P.E.; validation, D.K., S.E.N. and P.E.; formal analysis, P.E.; investigation, S.E.N. and P.E.; resources, D.A.M. and K.M.R. and R.L.C.; data curation, S.E.N. and P.E.; writing-original draft preparation, P.E.; writing-review and editing, D.K., S.E.N., D.A.M., K.M.R., R.L.C. and P.E.; visualization, S.E.N. and P.E.; supervision, D.K.; project administration, D.K.; funding acquisition, D.K. All authors have read and agreed to the published version of the manuscript.

Funding: The authors would like to acknowledge the following: National Eye Institute (NEI), National Institutes of Health (NIH) for the financial support (EY028888).

Institutional Review Board Statement: The study was conducted according to the guidelines of the Declaration of Helsinki and was performed by the North Texas Institutional Review Board (IRB) approval (protocol \#2020-031).

Informed Consent Statement: Written and informed consent was obtained prior to tissue collection.

Data Availability Statement: The data presented in this study are available on request from the corresponding author.

Acknowledgments: The authors would like to thank Dean McGee Eye Institute (DMEI) and Aarhus University Hospital for their assistance with human cornea samples.

Conflicts of Interest: The authors declare no conflict of interest.

\section{References}

1. $\quad$ Fink, B.A.; Wagner, H.; Steger-May, K.; Rosenstiel, C.; Roediger, T.; McMahon, T.T.; Gordon, M.O.; Zadnik, K. Differences in Keratoconus as a Function of Gender. Am. J. Ophthalmol. 2005, 140, 459.e1-459.e12. [CrossRef]

2. Gordon-Shaag, A.; Millodot, M.; Shneor, E.; Liu, Y. The Genetic and Environmental Factors for Keratoconus. BioMed Res. Int. 2015, 2015, 1-19. [CrossRef]

3. Brancati, F.; Valente, E.M.; Sarkozy, A.; Fehèr, J.; Castori, M.; Del Duca, P.; Mingarelli, R.; Pizzuti, A.; Dallapiccola, B. A locus for autosomal dominant keratoconus maps to human chromosome 3p14-q13. J. Med Genet. 2004, 41, 188-192. [CrossRef]

4. Ihalainen, A. Clinical and epidemiological features of keratoconus genetic and external factors in the pathogenesis of the disease. Acta Ophthalmol. Suppl. 1986, 178, 1-64.

5. Štabuc-Šilih, M.; Stražišar, M.; Hawlina, M.; Glavač, D. Absence of Pathogenic Mutations in VSX1 and SOD1 Genes in Patients With Keratoconus. Cornea 2010, 29, 172-176. [CrossRef]

6. Stabuc-Silih, M.; Strazisar, M.; Ravnik-Glavac, M.; Hawlina, M.; Glavac, D. Genetics and clinical characteristics of keratoconus. Acta Dermatovenerol. Alpina Pannonica Adriat. 2010, 19, 3-10.

7. Zadnik, K.; Mannis, M.J.; Johnson, C.A. An analysis of contrast sensitivity in identical twins with keratoconus. Cornea 1984, 3 , 99-103. [CrossRef] [PubMed]

8. Karamichos, D.; Barrientez, B.; Nicholas, S.; Ma, S.; Van, L.; Bak-Nielsen, S.; Hjortdal, J. Gonadotropins in Keratoconus: The Unexpected Suspects. Cells 2019, 8, 1494. [CrossRef] [PubMed]

9. McKay, T.B.; Hjortdal, J.; Sejersen, H.; Karamichos, D. Differential Effects of Hormones on Cellular Metabolism in Keratoconus In Vitro. Sci. Rep. 2017, 7, srep42896. [CrossRef] [PubMed]

10. A Balasubramanian, S.; Pye, D.C.; Willcox, M.D. Effects of eye rubbing on the levels of protease, protease activity and cytokines in tears: Relevance in keratoconus. Clin. Exp. Optom. 2013, 96, 214-218. [CrossRef] [PubMed]

11. Coyle, J.T. Keratoconus and Eye Rubbing. Am. J. Ophthalmol. 1984, 97, 527-528. [CrossRef]

12. Jafri, B.; Lichter, H.; Stulting, R.D. Asymmetric Keratoconus Attributed to Eye Rubbing. Cornea 2004, 23, 560-564. [CrossRef] [PubMed] 
13. Krachmer, J.H. Eye Rubbing Can Cause Keratoconus. Cornea 2004, 23, 539-540. [CrossRef] [PubMed]

14. Najmi, H.; Mobarki, Y.; Mania, K.; AlTowairqi, B.; Basehi, M.; Mahfouz, M.S.; Elmahdy, M. The correlation between keratoconus and eye rubbing: A review. Int. J. Ophthalmol. 2019, 12, 1775-1781. [CrossRef]

15. Armstrong, B.K.; Smith, S.D.; Coc, I.R.; Agarwal, P.; Mustapha, N.; Navon, S. Screening for Keratoconus in a High-Risk Adolescent Population. Ophthalmic Epidemiol. 2020, 28, 191-197. [CrossRef] [PubMed]

16. Naderan, M.; Jahanrad, A. Topographic, tomographic and biomechanical corneal changes during pregnancy in patients with keratoconus: A cohort study. Acta Ophthalmol. 2016, 95, e291-e296. [CrossRef]

17. Papali'I-Curtin, A.T.; Cox, R.; Ma, T.; Woods, L.; Covello, A.; Hall, R.C. Keratoconus Prevalence Among High School Students in New Zealand. Cornea 2019, 38, 1382-1389. [CrossRef]

18. Bilgihan, K.; Hondur, A.; Sul, S.; Ozturk, S. Pregnancy-induced Progression of Keratoconus. Cornea 2011, 30, 991-994. [CrossRef]

19. Hoogewoud, F.; Gatzioufas, Z.; Hafezi, F. Transitory Topographical Variations in Keratoconus during Pregnancy. J. Refract. Surg. 2013, 29, 144-146. [CrossRef]

20. Soeters, N.; Tahzib, N.G.; Bakker, L.; Van der Lelij, A. Two Cases of Keratoconus Diagnosed after Pregnancy. Optom. Vis. Sci. 2012, 89, 112-116. [CrossRef]

21. A Fink, B.; Sinnott, L.T.; Wagner, H.; Friedman, C.; Zadnik, K. The Influence of Gender and Hormone Status on the Severity and Progression of Keratoconus. Cornea 2010, 29, 65-72. [CrossRef] [PubMed]

22. McKay, T.B.; Hjortdal, J.; Sejersen, H.; Asara, J.M.; Wu, J.; Karamichos, D. Endocrine and Metabolic Pathways Linked to Keratoconus: Implications for the Role of Hormones in the Stromal Microenvironment. Sci. Rep. 2016, 6, 25534. [CrossRef] [PubMed]

23. Anton, N.; Doroftei, B.; Ilie, O.-D.; Ciuntu, R.-E.; Bogdănici, C.; Nechita-Dumitriu, I. A Narrative Review of the Complex Relationship between Pregnancy and Eye Changes. Diagn. 2021, 11, 1329. [CrossRef]

24. Naderan, M.; Jahanrad, A. Anterior, posterior and biomechanical parameters of cornea during pregnancy in healthy eyes: A cohort study. Br. J. Ophthalmol. 2017, 102, 309-312. [CrossRef] [PubMed]

25. Tabibian, D.; de Tejada, B.M.; Gatzioufas, Z.; Kling, S.; Meiss, V.S.; Boldi, M.-O.; Othenin-Girard, V.; Chilin, A.; Lambiel, J.; Hoogewoud, F.; et al. Pregnancy-induced Changes in Corneal Biomechanics and Topography Are Thyroid Hormone Related. Am. J. Ophthalmol. 2017, 184, 129-136. [CrossRef] [PubMed]

26. Aydin, E.; Demir, H.D.; Demirturk, F.; Calıskan, A.C.; Aytan, H.; Erkorkmaz, U. Corneal topographic changes in premenopausal and postmenopausal women. BMC Ophthalmol. 2007, 7, 9. [CrossRef]

27. Suzuki, T.; Kinoshita, Y.; Tachibana, M.; Matsushima, Y.; Kobayashi, Y.; Adachi, W.; Sotozono, C.; Kinoshita, S. Expression of sex steroid hormone receptors in human cornea. Curr. Eye Res. 2001, 22, 28-33. [CrossRef] [PubMed]

28. Yin, H.; Luo, C.; Tian, Y.; Deng, Y. Altered expression of sex hormone receptors in keratoconus corneas. Biomed Res. 2017, 28, 5089-5092.

29. Vécsei, P.V.; Kircher, K.; Kaminski, S.; Nagel, G.; Breitenecker, G.; Kohlberger, P.D. Immunohistochemical detection of estrogen and progesterone receptor in human cornea. Maturitas 2000, 36, 169-172. [CrossRef]

30. Wickham, L.A.; Gao, J.; Toda, I.; Rocha, E.; Ono, M.; Sullivan, D.A. Identification of androgen, estrogen and progesterone receptor mRNAs in the eye. Acta Ophthalmol. Scand. 2000, 78, 146-153. [CrossRef]

31. Gupta, P.; Johar, K.; Nagpal, K.; Vasavada, A. Sex Hormone Receptors in the Human Eye. Surv. Ophthalmol. 2005, 50, $274-284$. [CrossRef]

32. Ogueta, S.B.; Schwartz, S.D.; Yamashita, C.K.; Farber, D. Estrogen receptor in the human eye: Influence of gender and age on gene expression. Investig. Ophthalmol. Vis. Sci. 1999, 40, 1906-1911.

33. Munaut, C.; Lambert, V.; Noël, A.; Frankenne, F.; Deprez, M.; Foidart, J.-M.; Rakic, J.-M. Presence of oestrogen receptor type beta in human retina. Br. J. Ophthalmol. 2001, 85, 877-882. [CrossRef] [PubMed]

34. Rocha, F.J.; Wickham, L.A.; Pena, J.D.; Gao, J.; Ono, M.; Lambert, R.W.; Kelleher, R.S.; A Sullivan, D. Influence of gender and the endocrine environment on the distribution of androgen receptors in the lacrimal gland. J. Steroid Biochem. Mol. Biol. 1993, 46, 737-749. [CrossRef]

35. Sulliva, D.A.; Block, L.; Pena, J.D.O. Influence of androgens and pituitary hormones on the structural profile and secretory activity of the lacrimal gland. Acta Ophthalmol. Scand. 2009, 74, 421-435. [CrossRef] [PubMed]

36. Kennedy, R.H.; Bourne, W.M.; Dyer, J.A. A 48-Year Clinical and Epidemiologic Study of Keratoconus. Am. J. Ophthalmol. 1986, 101, 267-273. [CrossRef]

37. Spoerl, E.; Zubaty, V.; Raiskup-Wolf, F.; Pillunat, E.L. Oestrogen-induced changes in biomechanics in the cornea as a possible reason for keratectasia. Br. J. Ophthalmol. 2007, 91, 1547-1550. [CrossRef]

38. Walter, E.; Kormas, R.M.; Marcovich, A.L.; Lior, Y.; Sui, X.; Wagner, D.; Knyazer, B. The effect of estrogen and progesterone on porcine corneal biomechanical properties. Graefe's Arch. Clin. Exp. Ophthalmol. 2019, 257, 2691-2695. [CrossRef]

39. Tachibana, M.; Adachi, W.; Kinoshita, S.; Kobayashi, Y.; Honma, Y.; Hiai, H.; Matsushima, Y. Androgen-dependent hereditary mouse keratoconus: Linkage to an MHC region. Investig. Ophthalmol. Vis. Sci. 2002, 43, 51-57.

40. Iqbal, J.; Zaidi, M. Understanding Estrogen Action during Menopause. Endocrinology 2009, 150, 3443-3445. [CrossRef]

41. Cui, J.; Shen, Y.; Li, R. Estrogen synthesis and signaling pathways during aging: From periphery to brain. Trends Mol. Med. 2013, 19, 197-209. [CrossRef] [PubMed] 
42. Crescitelli, M.C.; Rauschemberger, M.B.; Cepeda, S.; Sandoval, M.; Massheimer, V.L. Role of estrone on the regulation of osteoblastogenesis. Mol. Cell. Endocrinol. 2019, 498, 110582. [CrossRef]

43. Liao, E.-Y.; Luo, X.-H.; Deng, X.-G.; Wu, X.-P.; Liao, H.-J.; Wang, P.-F.; Mao, J.-P.; Zhu, X.-P.; Huang, G.; Wei, Q.-Y. The effect of low dose nylestriol-levonorgestrel replacement therapy on bone mineral density in women with postmenopausal osteoporosis. Endocr. Res. 2003, 29, 217-226. [CrossRef] [PubMed]

44. Chollet, J.A.; Carter, G.; Meyn, L.A.; Mermelstein, F.; Balk, J.L. Efficacy and safety of vaginal estriol and progesterone in postmenopausal women with atrophic vaginitis. Menopause 2009, 16, 978-983. [CrossRef]

45. Natarajan, R.; Ravindran, R. Progression of keratoconus resulting from hormone replacement therapy. J. Cataract. Refract. Surg. 2019, 45, 1055. [CrossRef] [PubMed]

46. Coco, G.; Kheirkhah, A.; Foulsham, W.; Dana, R.; Ciolino, J.B. Keratoconus progression associated with hormone replacement therapy. Am. J. Ophthalmol. Case Rep. 2019, 15, 100519. [CrossRef] [PubMed]

47. Bjerregaard-Olesen, C.; Ghisari, M.; Kjeldsen, L.S.; Wielsøe, M.; Bonefeld-Jørgensen, E.C. Estrone sulfate and dehydroepiandrosterone sulfate: Transactivation of the estrogen and androgen receptor. Steroids 2016, 105, 50-58. [CrossRef]

48. Levitz, M.; Young, B.K. Estrogens in pregnancy. Vitam. Horm. 1977, 35, 109-147.

49. Yuksel, E.; Yalinbas, D.; Aydin, B.; Bilgihan, K. Keratoconus Progression Induced by In Vitro Fertilization Treatment. J. Refract. Surg. 2016, 32, 60-63. [CrossRef]

50. Feldman, F.; Bain, J.; Matuk, A.R. Daily Assessment of Ocular and Hormonal Variables Throughout the Menstrual Cycle. Arch Ophthalmol. 1978, 96, 1835-1838. [CrossRef]

51. Giuffrè, G.; Di Rosa, L.; Fiorino, F.; Bubella, D.M.; Lodato, G. Variations in Central Corneal Thickness During the Menstrual Cycle in Women. Cornea 2007, 26, 144-146. [CrossRef] [PubMed]

52. Ghahfarokhi, N.A.; Vaseghi, A.; Ghahfarokhi, N.A.; Ghoreishi, M.; Peyman, A.; Dehghani, A. Evaluation of corneal thickness alterations during menstrual cycle in productive age women. Indian. J. Ophthalmol. 2015, 63, 30-32. [PubMed]

53. Ayan, B.; Yuksel, N.; Carhan, A.; Ocal, B.G.; Akcay, E.; Cagil, N.; Asik, M.D. Evaluation estrogen, progesteron and androgen receptor expressions in corneal epithelium in keratoconus. Contact Lens Anterior Eye 2019, 42, 492-496. [CrossRef] [PubMed]

54. A Sullivan, D.; A Edwards, J.; A Wickham, L.; Pena, J.D.; Gao, J.; Ono, M.; Kelleher, R.S. Identification and endocrine control of sex steroid binding sites in the lacrimal gland. Curr. Eye Res. 1996, 15, 279-291. [CrossRef] [PubMed]

55. Mathers, W.D.; Stovall, D.; Lane, J.A.; Zimmerman, M.B.; Johnson, S. Menopause and tear function: The influence of prolactin and sex hormones on human tear production. Cornea 1998, 17, 353-358. [CrossRef]

56. Hu, Y.-C.; Wang, P.-H.; Yeh, S.; Wang, R.-S.; Xie, C.; Xu, Q.; Zhou, X.; Chao, H.-T.; Tsai, M.-Y.; Chang, C. Subfertility and defective folliculogenesis in female mice lacking androgen receptor. Proc. Natl. Acad. Sci. USA 2004, 101, 11209-11214. [CrossRef]

57. McKay, T.B.; Priyadarsini, S.; Rowsey, T.; Karamichos, D. Arginine Supplementation Promotes Extracellular Matrix and Metabolic Changes in Keratoconus. Cells 2021, 10, 2076. [CrossRef]

58. McKay, T.B.; Sarker-Nag, A.; Lyon, D.; Asara, J.M.; Karamichos, D. Quercetin modulates keratoconus metabolism in vitro. Cell Biochem. Funct. 2015, 33, 341-350. [CrossRef]

59. Priyadarsini, S.; McKay, T.B.; Sarker-Nag, A.; Karamichos, D. Keratoconus in vitro and the key players of the TGF-beta pathway. Mol. Vis. 2015, 21, 577-588.

60. Karamichos, D.; Hutcheon, A.E.K.; Rich, C.B.; Trinkaus-Randall, V.; Asara, J.M.; Zieske, J. In vitro model suggests oxidative stress involved in keratoconus disease. Sci. Rep. 2015, 4, 4608. [CrossRef] 